\title{
Combinatory approaches prevent preterm birth profoundly exacerbated by gene-environment interactions
}

\author{
Jeeyeon Cha, ${ }^{1}$ Amanda Bartos, ${ }^{1}$ Mahiro Egashira, ${ }^{2}$ Hirofumi Haraguchi, ${ }^{2}$ Tomoko Saito-Fujita, ${ }^{2}$ \\ Emma Leishman, ${ }^{3}$ Heather Bradshaw, ${ }^{3}$ Sudhansu K. Dey, ${ }^{1}$ and Yasushi Hirota ${ }^{1,2,4}$

\begin{abstract}
'Division of Reproductive Sciences, Perinatal Institute, Cincinnati Children's Research Foundation, Cincinnati, Ohio, USA.
2Department of Obstetrics and Gynecology, Graduate School of Medicine, University of Tokyo, Tokyo, Japan. ${ }^{3}$ Department of Psychological and Brain Sciences, Kinsey Institute for Research in Sex, Gender, and Reproduction, Indiana University, Bloomington, Indiana, USA.

${ }^{4}$ Precursory Research for Embryonic Science and Technology (PRESTO), Japan Science and Technology Agency, Saitama, Japan.
\end{abstract}

\begin{abstract}
There are currently more than 15 million preterm births each year. We propose that gene-environment interaction is a major contributor to preterm birth. To address this experimentally, we generated a mouse model with uterine deletion of $\operatorname{Trp53}$, which exhibits approximately $50 \%$ incidence of spontaneous preterm birth due to premature decidual senescence with increased mTORC1 activity and COX2 signaling. Here we provide evidence that this predisposition provoked preterm birth in $100 \%$ of females exposed to a mild inflammatory insult with LPS, revealing the high significance of gene-environment interactions in preterm birth. More intriguingly, preterm birth was rescued in LPS-treated Trp53-deficient mice when they were treated with a combination of rapamycin (mTORC1 inhibitor) and progesterone $\left(\mathrm{P}_{4}\right)$, without adverse effects on maternal or fetal health. These results provide evidence for the cooperative contributions of two sites of action (decidua and ovary) toward preterm birth. Moreover, a similar signature of decidual senescence with increased mTORC1 and COX2 signaling was observed in women undergoing preterm birth. Collectively, our findings show that superimposition of inflammation on genetic predisposition results in high incidence of preterm birth and suggest that combined treatment with low doses of rapamycin and $P_{4}$ may help reduce the incidence of preterm birth in high-risk women.
\end{abstract}

\section{Introduction}

Preterm birth in humans, defined as parturition occurring prior to 37 weeks of gestation, is still a global problem. One in 10 babies is born preterm worldwide, accounting annually for more than 15 million premature births (1-4). With more than 1 million deaths attributed to complications arising from prematurity each year, preterm birth is a leading cause of neonatal death $(1,5,6)$. In addition, premature babies who survive are at increased risk for a number of health challenges, including respiratory distress, underdeveloped organ systems, and cerebral palsy with learning and developmental disabilities $(1,2,7)$. Several risk factors, including genetic predisposition, infection/inflammation, oxidative stress, short cervix, progesterone $\left(\mathrm{P}_{4}\right)$ resistance, increased maternal age, and stretch signaling originating from multiple pregnancy, contribute to this multifactorial disorder $(1,8)$. Due to its complex nature, mechanisms underpinning preterm birth are not clearly understood.

While more than $60 \%$ of preterm births occur in developing countries in Africa and South Asia, a recent report from the WHO identified the United States as being among the ten countries with the highest numbers of preterm birth (1), underscoring the global nature of this problem. Etiologies behind high preterm birth rates in developing and developed countries may be disparate - infection/ inflammation affects developing countries more, while assisted reproductive technology (ART) compounded by increased maternal age at conception as well as increased prevalence of diabetes and high

Conflict of interest: The authors have declared that no conflict of interest exists. Citation for this article: J Clin Invest. 2013;123(9):4063-4075. doi:10.1172/JCI70098. blood pressure are additional risk factors in developed countries (1). These observations suggest that preterm birth is the end result of many different causative factors. Therefore, multiple approaches and model systems are warranted in addressing this problem.

Mechanistic preclinical studies utilizing mouse models of preterm birth should help in addressing this problem. Inflammatory mediators such as endotoxin (LPS) and inflammatory cytokines (such as IL-1 $\beta$, IL-6, and TNF- $\alpha$ ) are known to induce preterm labor coincident with ovarian luteolysis with a decrease in serum $\mathrm{P}_{4}$ levels (9). Along the same lines, administration of RU-486 (mifepristone), a progesterone receptor (PR) antagonist, leads to similar effects $(8,10)$. However, these mouse models may not adequately define the mechanism of parturition timing, since human preterm birth is considered to occur without a drop in serum $\mathrm{P}_{4}$ levels (11), although further studies are required to assess $\mathrm{P}_{4}$ levels accounting for disparate etiologies of preterm birth.

Mouse and human studies have shown that aberrations in early pregnancy can be propagated during the subsequent course of pregnancy and lead to compromised pregnancy outcomes, including preterm birth (12). We have generated a mouse model harboring a conditional uterine deletion of $\operatorname{Tr} p 53$, encoding tumor suppressor protein $\mathrm{p} 53\left(\operatorname{Trp} 53^{\text {loxP/loxP }} \mathrm{Pgr}^{\mathrm{Cre} /+}\right)$. These mice exhibit premature decidual senescence associated with heightened mTORC1 signaling early in pregnancy. Strikingly, they show genetic predisposition to preterm birth; approximately $50 \%$ incidence of spontaneous preterm delivery with fetal death and dystocia is observed in these females without a drop in serum $\mathrm{P}_{4}$ levels (13). Progressive decidual senescence was coincident with aberrantly higher levels of COX2 and prostaglandin F synthase (PGFS), reflected in increased uterine levels of 
Table 1

p53 $3^{d / d}$ mice are more susceptible to inflammation-induced preterm birth

\begin{tabular}{|c|c|c|c|c|c|}
\hline Treatment & Genotype & Time of delivery & No. of dams & Rate of preterm birth & $\begin{array}{c}\% \text { Dead pups and resorptions/ } \\
\text { total number of pups }\end{array}$ \\
\hline \multirow[t]{3}{*}{$75 \mu \mathrm{g}$ LPS } & $p 53^{f / / f l}$ & Day 17 0800h-1800h & 5 & $83 \%(5)$ & $100 \%(32 / 32)$ \\
\hline & & Day $191800 \mathrm{~h}$ to day $200800 \mathrm{~h}$ & $1^{A}$ & $0 \%(0)$ & $67 \%(6 / 9)$ \\
\hline & & Total & 6 & $83 \%(5)$ & $93 \%(38 / 41)$ \\
\hline $50 \mu \mathrm{g}$ LPS & $p 53^{f / / f l}$ & Day 17 0800h-1800h & 7 & $71 \%(5)$ & $67 \%(45 / 67)$ \\
\hline \multirow[t]{4}{*}{$37 \mu \mathrm{g}$ LPS } & $p 53^{f / / f l}$ & Day $191800 \mathrm{~h}$ to day $200800 \mathrm{~h}$ & 5 & $0 \%(0)$ & $0 \%(0 / 44)$ \\
\hline & $p 53^{\mathrm{d} / \mathrm{d}}$ & Day 17 1200h-1800h & 1 & $25 \%(1)$ & $100 \%(8 / 8)$ \\
\hline & & Day $171800 \mathrm{~h}$ to day $181800 \mathrm{~h}$ & 3 & $75 \%(3)$ & $100 \%(25 / 25)$ \\
\hline & & Total & 4 & $100 \%(4)$ & $100 \%(33 / 33)$ \\
\hline \multirow[t]{5}{*}{$10 \mu \mathrm{g}$ LPS } & $p 53^{f \mid / f l}$ & Day $190800 \mathrm{~h}$ to day $210800 \mathrm{~h}$ & 12 & $0 \%(0)$ & $1 \%(1 / 99)$ \\
\hline & $p 53^{d / d}$ & Day $161700 \mathrm{~h}$ to day $170800 \mathrm{~h}$ & 3 & $15 \%(3)$ & $100 \%(16 / 16)$ \\
\hline & & Day 17 0800h-1800h & 13 & $65 \%(13)$ & $95 \%(81 / 85)$ \\
\hline & & Day $171800 \mathrm{~h}$ to day $181800 \mathrm{~h}$ & 4 & $20 \%(4)$ & $100 \%(19 / 19)$ \\
\hline & & Total & 20 & $100 \%(20)$ & $94 \%(113 / 117)$ \\
\hline
\end{tabular}

Littermate $p 53^{f / / f l}\left(\operatorname{Trp5} 3^{\text {loxPlloxP } P g r^{+/+}}\right)$and $p 53^{d / d}\left(\operatorname{Trp53/oxP/loxP} P g r^{C r e /+}\right)$ dams were used. Time of delivery is defined as the day of pregnancy when the dam first started delivering pups. Preterm birth is defined as delivery occurring before day 19 of pregnancy. LPS was administered i.p. on day 16 of pregnancy at $1200 \mathrm{~h}$. The rate of preterm birth was calculated as the number of females exhibiting preterm birth over the total number of females examined within a treatment group, while numbers in parentheses indicate the number of females. The percentage of dead pups and resorptions was calculated over the total number of pups delivered, while numbers in parentheses indicate their absolute numbers. AOne dam lost weight daily from days 16 through 19 of pregnancy, indicative of resorption, with 3 live pups; 9 placental scars were observed when the uterus was exposed post mortem.

$\mathrm{PGF}_{2 \alpha}$, triggering myometrial contractility in a paracrine manner to induce preterm birth (13). These results led us to speculate that targeting COX2 and/or mTORC1 signaling could prevent preterm birth in this model. Indeed, we were successful in preventing preterm birth in $\operatorname{Trp}^{5} 3^{\text {loxP/loxP }} \mathrm{Pgr} \mathrm{Cre}^{\mathrm{C}+}$ females by oral gavage of celecoxib, a selective inhibitor of COX2, on day 16 of pregnancy or by inhibition of mTORC1 signaling by a low dose of rapamycin, which attenuated the progression of premature decidual senescence $(13,14)$.

Preterm birth is the result of many contributing factors, including genetic predisposition and environmental insults. Although gene-environment interactions are thought to contribute to the disease process, this concept has not been experimentally tested in a predisposed model. Our current studies provide evidence-based proof of principle that when genetic predisposition is superimposed with inflammation, the rate of preterm birth is profoundly enhanced. We show that $\operatorname{Trp} 53^{\text {loxP/loxP }} \mathrm{Pgr} \mathrm{Cre}^{+}+$females exposed to even a mild inflammatory insult are exquisitely susceptible to preterm birth, with a decrease in $\mathrm{P}_{4}$ levels. Intriguingly, combination therapy with rapamycin and $\mathrm{P}_{4}$ targeting both the decidual senescence imposed by Trp53 deletion and the inflammatory insult can effectively rescue preterm birth. These findings point to gene-environment interactions in preterm birth through cooperative contributions of at least two sites of action (decidua and ovary) and an effective preventative strategy.

These studies in mice prompted us to assess whether similar signaling pathways are operative in human preterm delivery. We present evidence that a signature of decidual senescence with increased mTORC1 signaling and COX2 expression is active in human preterm birth. Superficial decidual cells adherent to the term placentae of women were isolated for culture and showed increased levels of the inflammatory mediators IL- 6 and IL- 8 in the presence of TLR4-specific LPS, but their levels were reduced by addition of $\mathrm{P}_{4}$ and/or rapamycin. Collectively, the results suggest a close relationship between genetic predisposition and environmental insults in exacerbating preterm delivery.

\section{Results}

$\operatorname{Trp} 53^{\text {loxP } / \text { loxP }} \mathrm{Pgr} \mathrm{gre} /{ }^{+}$mice show increased sensitivity to inflammation-induced preterm birth. To generate mice with uterine-specific deletion of Trp53, we mated $\operatorname{Tr} p 53^{\operatorname{loxp} / \operatorname{lox} P}$ females with males expressing Cre recombinase driven by the $\mathrm{Pg} r$ promoter $\left(\mathrm{Pgr}^{\mathrm{Cre} /}+\right)$, as previously described $(13,14)$. $\operatorname{Tr} 553^{\text {loxP } / \text { loxP } P g r C r e /+}$ females show approximately $50 \%$ incidence of spontaneous preterm delivery with dystocia and fetal death compared with floxed littermates showing normal pregnancy outcome; preterm delivery is defined as birth occurring before day 19 of pregnancy (14). To compare the sensitivity of these females to inflammation with respect to preterm birth, we injected TLR4-specific LPS

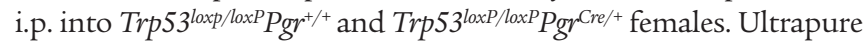
LPS was used to avoid contamination by other TLR agonists normally found in commercial preparations that are often used in preterm birth studies. $\operatorname{Trp} 53^{\operatorname{loxp} / \operatorname{lox} P} \mathrm{Pgr} r^{+/+}$females showed $100 \%$ incidence of preterm birth and/or fetal resorption and death when injected with $75 \mu \mathrm{g}$ TLR4-specific LPS on day 16 of pregnancy. While a dose of even $50 \mu \mathrm{g}$ was quite effective in inducing preterm birth (71\%), lower doses of LPS (10 or $37 \mu \mathrm{g})$ were ineffective in inducing preterm birth in floxed females (Table 1). Remarkably, an injection of $10 \mu \mathrm{g}$ LPS on day 16 induced preterm birth with stillbirth in all $\operatorname{Trp} 53^{\text {loxP/loxP } P g r C r e /+}$ littermates examined $(n=20)$. These results clearly demonstrate that these females are exquisitely sensitive to preterm delivery.

Trp53 loxP/loxP Pgr Cre/+ females show exaggerated uterine prostaglandin production. Prostaglandins (PGs) are normally generated by the COX system, which exists in two isoforms, COX1 and COX2. While constitutive COX1 is considered to maintain basal levels of PGs, COX2-induced PGs are normally generated by inflammatory stimuli and are known to participate in parturition $(13,15,16)$. Among various PGs, $\mathrm{PGF}_{2 \alpha}$ is implicated in parturition timing by synchronizing myometrial contractility. We have previously shown that levels of uterine COX1 remains unaltered in $\operatorname{Trp} 53^{\text {loxP } / \text { loxP } P g r^{+/+}}$and $\operatorname{Tr} p 53^{\text {loxP } / \text { loxP }} \mathrm{Pgr} \mathrm{Cre}^{++}$females, while uterine COX2 levels are upregulated in $\operatorname{Tr} p 53^{\text {loxP } / \text { loxP }} \mathrm{PgrCre} /+$ females, with increased levels of PGFS and $\operatorname{PGF}_{2 \alpha}(13)$. We also found that 
A
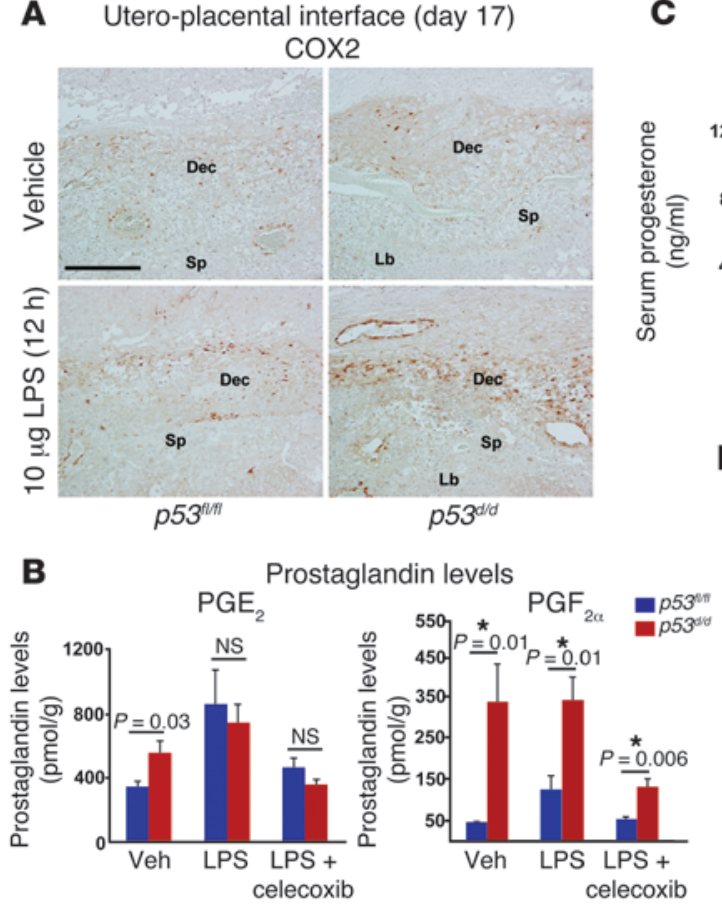

C

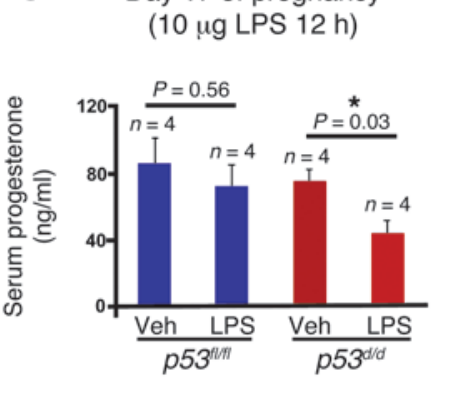

D Ovary (day 17 of pregnancy) Akr1c18 $P=0.004 P=0.039$

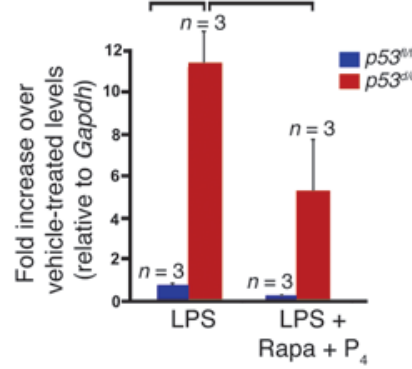

E

20aHSD

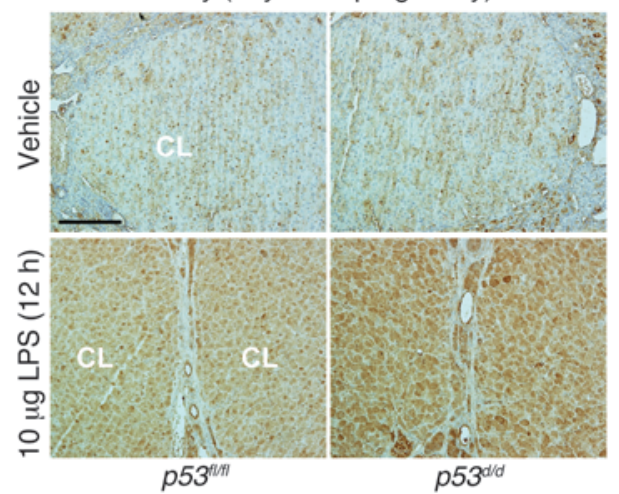

Ovary (day 20 of pregnancy)

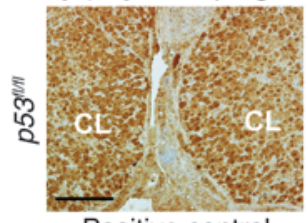

Positive control

\section{Figure 1}

Mild inflammatory insult in $p 53^{d / d}$ female mice upregulates decidual COX2 signaling and renders ovaries more sensitive to luteolysis. (A) Immunohistochemistry showed upregulated COX2 expression in the decidua of Trp53/loxP/loxP PgrCre/+ $\left(p 53^{d / d}\right)$ mice 12 hours after an injection of $10 \mu \mathrm{g}$ LPS at $1900 \mathrm{~h}$ on day 16 of pregnancy. Dec, decidua; Sp, spongiotrophoblast; Lb, labyrinth. Scale bar: $250 \mu \mathrm{m}$. (B) Mass spectrometric analysis showed that uterine levels of $\mathrm{PGF}_{2 \alpha}$, but not $\mathrm{PGE}_{2}$, are significantly upregulated in LPS-treated $p 53^{d / d}$ females as compared with Trp53/oxP/loxP Pgr+/+ $\left(p 53^{f / / f f}\right)$ littermates. This upregulation was suppressed by celecoxib treatment. Three to 6 independent samples isolated from each mouse were analyzed $\left(n=3-5\right.$ mice/treatment group; mean \pm SEM; $\left.{ }^{*} P<0.05\right)$. (C) Serum $\mathrm{P}_{4}$ levels were measured 12 hours after LPS or

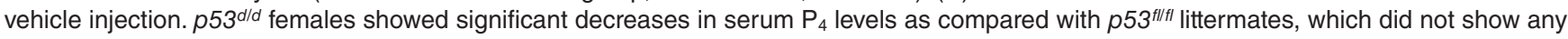
significant differences (mean $\pm \mathrm{SEM} ;{ }^{*} P<0.05$ ). (D) qPCR results showed significant upregulation of $A k r 1 c 18$ in ovaries of $p 53^{d / d}$ females after

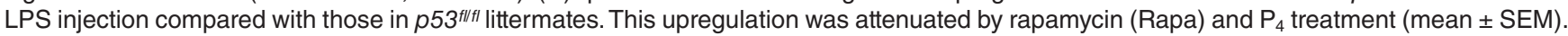
(E) Immunohistochemistry for $20 \alpha \mathrm{HSD}$ in $\mathrm{CL}$ of vehicle-treated $p 53^{f / f l}$ and $p 53^{d / d}$ females showed similar signal levels, as compared with increased signal levels in CL of $p 53^{d / d}$ females 12 hours after LPS injection, albeit with some increases in $p 53^{\text {fl/fI }} \mathrm{CL}$. As expected, sections of ovaries from $p 53^{f / l f l}$ females on day 20 of pregnancy prior to parturition showed higher expression of $20 \alpha H S D$ (positive control). Scale bars: $100 \mu \mathrm{m}$.

upregulation of COX2 primarily occurs in the decidua, suggesting that decidua-derived $\mathrm{PGF}_{2 \alpha}$ causes myometrial contractions in a paracrine manner.

In the present study, we found that COX2 immunostaining was more intense in deciduae and endothelial cells of decidual vasculature of $\operatorname{Trp} 53^{\operatorname{lox} P / \operatorname{lox} P} \mathrm{Pgr} C \mathrm{Cre} /+$ females as compared with $\operatorname{Tr} p 53^{\operatorname{lox} P / \operatorname{lox} P}$ $\mathrm{Pgr}^{+/+}$females after 12-hour treatment with a low dose of LPS $(10 \mu \mathrm{g})$ given on day 16 of pregnancy (Figure 1A). Increases in decidual COX2 levels in $\operatorname{Trp} 53^{\text {loxP/loxP } P g r C r e /+}$ females after exposure to LPS were also reflected in higher levels of $\mathrm{PGF}_{2 \alpha}$ without alterations in $\mathrm{PGE}_{2}$ levels, as determined by mass spectrometric analysis (Figure 1B). Notably, these increased levels were similar to those in untreated $\operatorname{Tr} p 53^{\text {loxP/loxP }} \mathrm{Pgr} \mathrm{Cre}^{++}$females, but much higher than in $\operatorname{Trp} 53^{\text {loxP/loxP }} \mathrm{Pgr}^{+/+}$mice treated with LPS. Increased levels of $\mathrm{PGF}_{2 \alpha}$ after LPS administration were attenuated by oral administration of celecoxib. These results raised the question of how even a small insult results in such profound effects on preterm birth. Notably, acute exposure to LPS did not increase the intensity of senescenceassociated $\beta$-gal staining (SA- $\beta$-gal), an established marker of cellular senescence, which was already higher in $\operatorname{Tr} p 53^{\text {loxP/loxP }} \mathrm{Pgr} \mathrm{Cre} /+$ deciduae (Supplemental Figure 1; supplemental material available online with this article; doi:10.1172/JCI70098DS1).

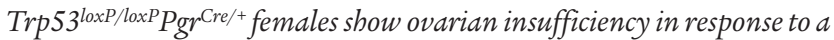
mild inflammatory stimulus. $\mathrm{P}_{4}$ is an absolute requirement for pregnancy success, and withdrawal of $\mathrm{P}_{4}$ signaling is critical for parturition (12). Therefore, we examined whether the ovarian output of $\mathrm{P}_{4}$ is altered in the $\operatorname{Tr} p 53^{\text {loxP/loxP }} \mathrm{Pgr}$ Cre/t+ females receiving $10 \mu \mathrm{g}$ LPS. Large doses of LPS ranging from 50 to $250 \mu \mathrm{g}$ have been shown to induce ovarian luteolysis (9), the functional and structural disintegration of corpora lutea (CL); this process triggers a rapid decrease in serum $\mathrm{P}_{4}$ levels, leading to preterm birth or pregnancy termination in rodents $(9,17)$, although other systemic responses cannot be ruled out. Normally, Trp5 $53^{\operatorname{lox} P / \operatorname{lox} P} \mathrm{Pgr} \mathrm{Cre} /+$ females do not show ovarian luteolysis or a decrease in serum $\mathrm{P}_{4}$ levels but still exhibit approximately $50 \%$ spontaneous preterm birth (13). In the present investigation, we found that an injection of even $10 \mu \mathrm{g}$ LPS in Trp53 $3^{\text {loxP/loxP }} \mathrm{Pgr}{ }^{\mathrm{Cr} /+}+$ females on day 16 of pregnancy triggered a drop in serum $\mathrm{P}_{4}$ levels 12 hours after injection (Figure 1C). This was reflected in higher expression of ovarian Akr1c18, encoding mouse $20 \alpha$-hydroxysteroid dehydrogenase

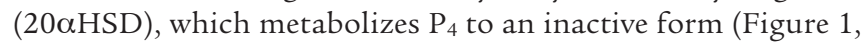
$\mathrm{D}$ and $\mathrm{E})$. No significant drop in $\mathrm{P}_{4}$ levels nor increased $20 \alpha \mathrm{HSD}$ expression at the mRNA or protein levels was noted in Trp53loxP/loxP $\mathrm{Pgr}^{+/+}$females after such treatment. As previously shown by oth- 
A

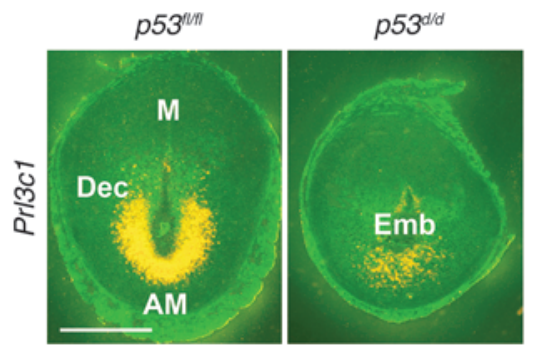

Day 8 of pregnancy

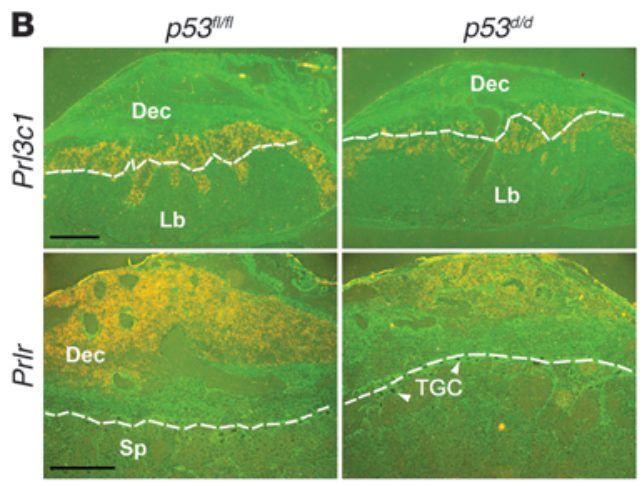

Day 16 of pregnancy

ers $(18,19)$, ovarian insufficiency in LPS-treated $\operatorname{Trp} 53^{\operatorname{lox} P / \operatorname{lox} P}$ $P g r^{C r e /+}$ females was also reflected in upregulation of Socs 1 and Socs 3 expression (Supplemental Figure 2, A and B). These results suggest that ovaries in $\operatorname{Trp} 53^{\operatorname{lox} P / \operatorname{lox} P} \mathrm{Pgr} r^{\mathrm{Cr} /} /{ }^{+}$mice are more sensitive to luteolysis even with a mild environmental insult, raising the question regarding the mechanism for the heightened sensitivity of $\operatorname{Trp} 53^{\text {loxP/loxP }} \mathrm{Pgr} \mathrm{Cre}^{++}$females to ovarian luteolysis with inflammatory stimulus, leading to preterm birth.

$\operatorname{Tr} p 53^{\text {loxP } / l o x P} P \mathrm{gr}^{\mathrm{Cre} /+}$ females express reduced levels of decidual prolactinlike protein J and prolactin receptor. It is known that decidua-derived factors serve as luteotrophins to extend the lifespan of the CL and maintain luteal $\mathrm{P}_{4}$ secretion in rodents (20-22). In fact, experimentally induced decidualization in pseudopregnant rats extends the CL lifespan with continued $\mathrm{P}_{4}$ secretion, as opposed to shortened CL lifespan in pseudopregnant rats without decidualization (23). Our recent proteomics analysis found downregulation of a decidua-enriched prolactin-like hormone, prolactin-like protein J (PLP-J), in Trp53 loxP/loxP PgrCre/+ deciduae (24). PLP-J was identified in rat decidua and is implicated in maintaining decidual cell survival (25-28). Our in situ hybridization results show that Prl3c1, encoding PLP-J, was highly expressed in the decidua surrounding the developing embryo on day 8 in $\operatorname{Trp} 53^{\text {loxP/loxP }} \mathrm{Pgr}^{+/+}$females but was markedly downregulated in $\operatorname{Tr} p 53^{\text {loxP } / \text { loxP } P g r C r e /+}$ deciduae, consistent with our previous proteomics results (Figure 2A). We also found that expression of this gene was downregulated at the decidual-placental interface in $\operatorname{Trp}^{5} 3^{\operatorname{lox} P / \operatorname{lox} P} \mathrm{Pgr} \mathrm{Cre}^{\mathrm{H}}$ females on day 16 (Figure 2B). Immunolocalization of CDX2 demarcated trophoblast cell invasion into the decidual bed on this day of pregnancy (Supplemental Figure 3). Prolactin receptor (Prlr), which is also expressed in the decidua $(29,30)$, was downregulated in this tissue on day 16 (Figure 2B). These results suggest that decidual health is inferior in $\operatorname{Trp} 53^{\text {loxP/loxP } P g r C r e /+}$ females, which compromises its luteotrophic task, making the CL more vulnerable to even a small insult.

\section{Figure 2}

Expression of Prl3c1 and Prlr is downregulated in decidua and the decidual-placental interface in $p 53^{d / d}$ females. (A) In situ hybridization of Prl3c1 in $p 53^{f / f l}$ and $p 53^{d / d}$ deciduae on day 8 of pregnancy showing significant downregulation in $p 53^{d / d}$ decidua. Scale bar: $1 \mathrm{~mm}$. (B) In

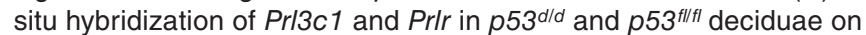
day 16 of pregnancy, again showing downregulation in $p 53^{d / d}$ females. Dotted lines demarcate the location of trophoblast giant cells (TGC) at the decidual-placental interface. Scale bar for Prl3c1: $1 \mathrm{~mm}$; for Prlr: 500 um. Emb, embryo; AM, antimesometrial pole; M, mesometrial pole; Lb, labyrinth.

Rapamycin and $P_{4}$ with or without celecoxib rescue preterm birth in $\operatorname{Trp5} 3^{\text {loxP } / \text { loxP }} \mathrm{Pgr}^{\mathrm{Cre} /+}$ females exposed to a low dose of LPS. As reported previously $(13,14)$, administration of either celecoxib or rapamycin rescues spontaneous preterm birth in $\operatorname{Trp} 53^{\operatorname{loxP} / \text { loxP } P g r C r e /+}$ females without any apparent adverse effects on the dam or fetuses. These results led us to test whether this treatment would effectively reverse inflammation-exaggerated preterm birth in $\operatorname{Tr} p 53^{\operatorname{lox} P / / \text { ox } P}$ $\mathrm{Pgr}^{\mathrm{Cre} / \mathrm{+}}$ females. First, we used rapamycin or celecoxib singly and found them to be insufficient in preventing LPS-induced preterm birth (Supplemental Figure 4 and Supplemental Table 1). We also found that although $\mathrm{P}_{4}(2 \mathrm{mg})$ supplementation prior to and after LPS injection extended the parturition timing in $\operatorname{Tr} p 53^{\text {loxP/loxP } P g r C r e /+}$ females, higher rates of fetal death and/or stillbirth were frequently encountered under this condition (Supplemental Table 1). Moreover, a combination treatment of celecoxib plus rapamycin or of celecoxib and $\mathrm{P}_{4}$ did not rescue preterm birth in Trp53loxP/loxP $\mathrm{Pgr}_{\mathrm{Cre} /+}$ females exposed to LPS (Supplemental Table 1). We next asked whether combinatory treatments with celecoxib, $\mathrm{P}_{4}$, and/or rapamycin would rescue preterm birth with neonatal survival. Both floxed and deleted mice received an oral gavage of rapamycin $(0.25 \mathrm{mg} / \mathrm{kg} \mathrm{BW})$ on days 8,12 , and 16 of pregnancy, followed by an oral gavage of celecoxib (10 mg/kg BW) twice on day 16 , once 3 hours prior to and 4 hours after LPS $(10 \mu \mathrm{g})$ injection. In addition, $\mathrm{P}_{4}$ was given twice on day 16 at around the same time points as celecoxib. This combination treatment rescued preterm birth in $\operatorname{Tr} 553^{\text {loxP } / \text { loxP } P g r C r e /+}$ females exposed to LPS, with survival of a full complement of pups (Figure 3, A-C, and Supplemental Table 2); maternal weight gain due to fetal growth from day 16 to delivery and neonatal pup growth over a period of 10 days were comparable to those of untreated $\operatorname{Trp} 53^{\operatorname{lox} P / \operatorname{lox} P} \mathrm{Pgr}^{+/+}$females with term delivery (Supplemental Figure 5, A and B). However, this treatment schedule adversely affected fetal viability, with high incidence of resorption in littermate $\operatorname{Trp} 53^{\operatorname{loxP} / \operatorname{lox} P} \mathrm{Pgr}^{+/+}$females (Figure 3C). These results were surprising and led us to reevaluate our approach to treating LPS-induced preterm birth in Trp5 $53^{\text {loxP/loxP } P g r C r e /+}$ females without incurring adverse effects on fetal survival in control floxed littermates. We found that a combination of rapamycin and $\mathrm{P}_{4}$ was not only sufficient to rescue preterm birth in $\operatorname{Tr} p 53^{\text {loxP } / \text { loxP } P g r C r e /+}$ females, but also did not significantly alter pregnancy outcome in $\operatorname{Trp} 53^{\text {loxP } / l o x P} \mathrm{Pgr}^{+/+}$females (Figure 3, A-C, and Supplemental Table 2). Again, this treatment did not interfere with maternal weight gain due to fetal growth during pregnancy or neonatal growth over a period of 10 days in either group (Supplemental Figure 5, A and B). An alternative schedule of rapamycin treatment on days 8,10 , and 12 of pregnancy with $\mathrm{P}_{4}$ on day 16 was also effective in rescuing preterm birth in Trp53 $3^{\text {loxP/loxP } P g r C r e /+}$ females and did not result in adverse pregnancy outcome in $\operatorname{Trp} 53^{\text {loxP } / l o x P} \mathrm{Pgr}^{+/+}$females (Supplemental Table 3). The combined treatment of rapamycin and $\mathrm{P}_{4}$ 
A

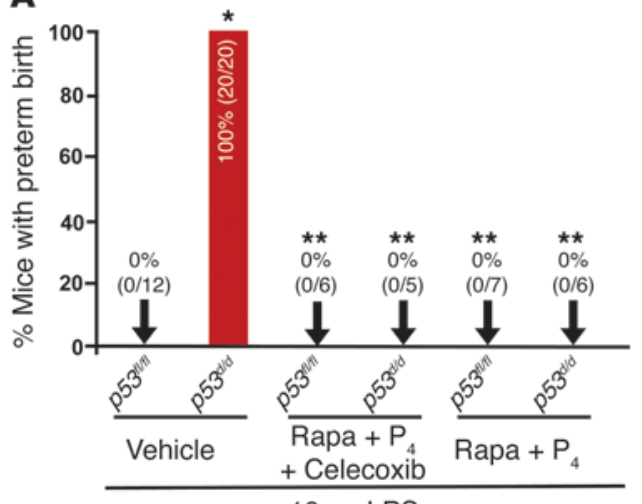

$10 \mu \mathrm{g}$ LPS

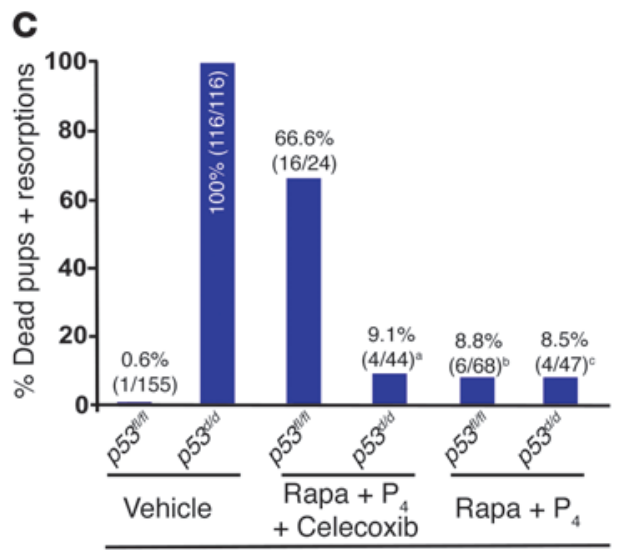

E

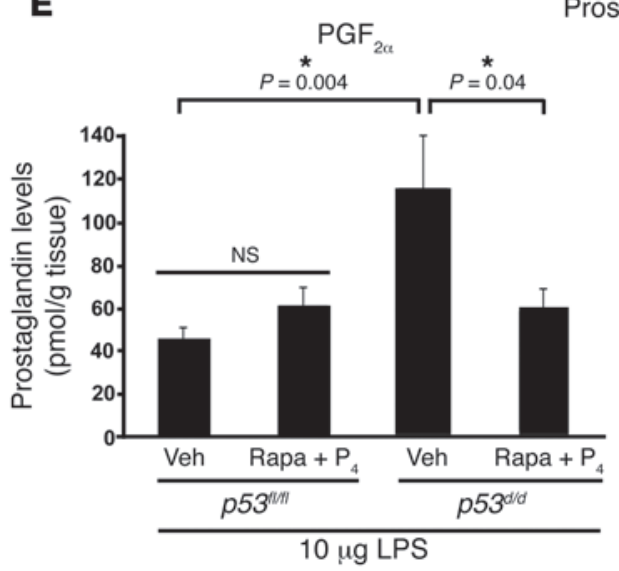

B

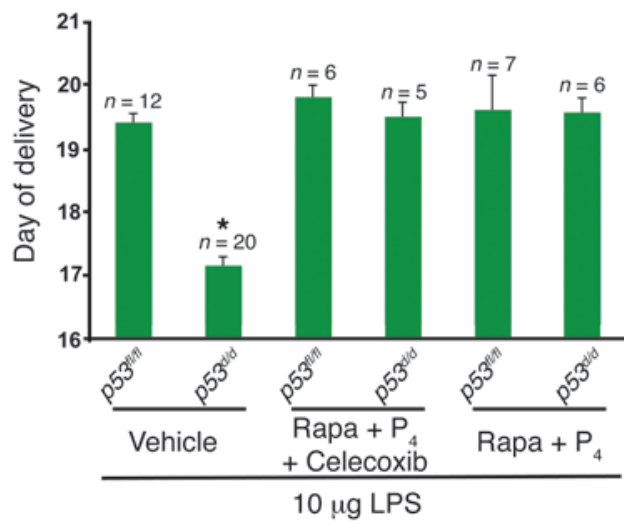

D Utero-placental interface (day 16)

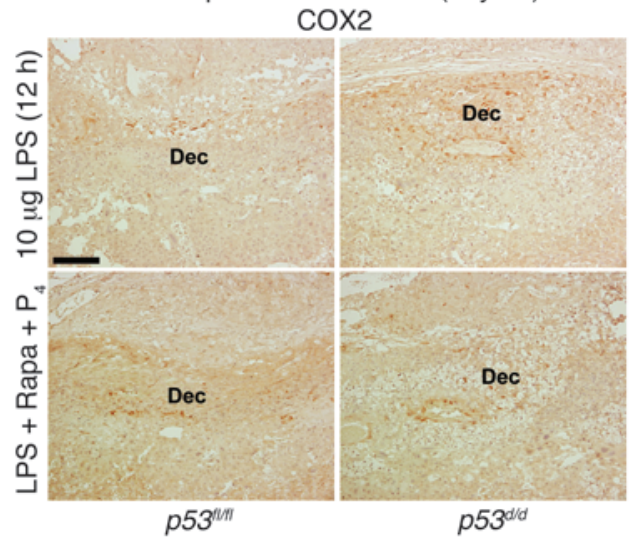

\section{Figure 3}

Preterm birth in $p 53^{d / d}$ females was effectively rescued with combined treatment of rapamycin and $\mathrm{P}_{4}$, without adverse effects on pregnancy outcome. (A) All $p 53^{\text {d/d }}$ females examined under mild inflammation $(10 \mu \mathrm{g}$ LPS) showed preterm birth, which was rescued by a combination of rapamycin (Rapa) and $\mathrm{P}_{4}$ treatment with or without celecoxib (mean \pm SEM; ${ }^{*} P<0.05$ compared with vehicle-treated control females; ${ }^{\star \star} P<0.05$ compared with LPS-treated females). (B) $p 53^{d / d}$ females with these treatment schedules showed rescue of preterm birth as assessed by the day of delivery (mean \pm SEM; ${ }^{*} P<0.05$ ). (C) Combined treatment with rapamycin, $\mathrm{P}_{4}$, and celecoxib adversely affects fetal health in $p 53^{f / f l}$ females, but treatment with $\mathrm{P}_{4}$ and rapamycin does not. $a, b$, and $c$ denote dead pups/resorption sites in one dam in each group (see Supplemental Table 2). (D) Immunohistochemistry for COX2 in deciduae of LPStreated $p 53^{d / d}$ females showed decreased signals after treatment with rapamycin and $\mathrm{P}_{4}$. Scale bar: $200 \mu \mathrm{m}$. (E) Mass spectrometric analysis of PGs shows that treatment with rapamycin and $\mathrm{P}_{4}$ significantly lowered $\mathrm{PGF}_{2 \alpha}$ levels in $p 53^{d / d}$ uteri challenged with LPS; uterine $\mathrm{PGE}_{2}$ levels were not significantly different in similarly treated $p 53^{f / f l}$ and $p 53^{d / d}$ females. Three to 6 independent samples isolated per animal were analyzed $(n=3-5$ mice/ treatment group; mean \pm SEM; $\left.{ }^{*} P<0.05\right)$. Veh, vehicle. prevented an increase in decidual COX2 (Figure 3D and Supplemental Figure 6), and this was reflected in reduced levels of PGF $2 \alpha$ compared with those in $\operatorname{Trp} 53^{\text {loxP/loxP }} \mathrm{Pgr}{ }^{\mathrm{Cre} /+}$ females treated with LPS alone (Figure 3E). Rapamycin and $\mathrm{P}_{4}$ treatment also reduced the expression level of ovarian Akr1c18 in LPS-treated Trp53 loxP/loxP $\mathrm{Pgr} \mathrm{Cre} /+$ females (Figure 1D), along with downregulation of ovarian Socs 1 and Socs 3 expression (Supplemental Figure 2). Collectively, these results point toward a potential therapeutic application for this combination treatment in preterm birth.

Higher mTORC1 signaling is correlated with increased senescence and upregulation of COX2 expression in human preterm deciduae. The next objective was to see whether our findings in mice were applica- ble in the case of human preterm birth. Placentae to which the decidua basalis remained adherent were collected from women following vaginal delivery at term (37-41 weeks of gestation) and preterm (25-36 weeks); the etiology of preterm birth ranged from unknown to diagnosed infection (Supplemental Table 4). When placental-decidual sections were processed for SA- $\beta$-gal staining, we found clear evidence of positive $\beta$-gal staining in preterm deciduae, with little or no staining in term deciduae (Figure 4A, Supplemental Figure 7A, and Supplemental Figure 8). We also found increased intensity of nuclear immunolocalization of $\gamma \mathrm{H} 2 \mathrm{AX}$, another marker of senescence associated with DNA damage response, in preterm deciduae (Figure 4B, Supple- 

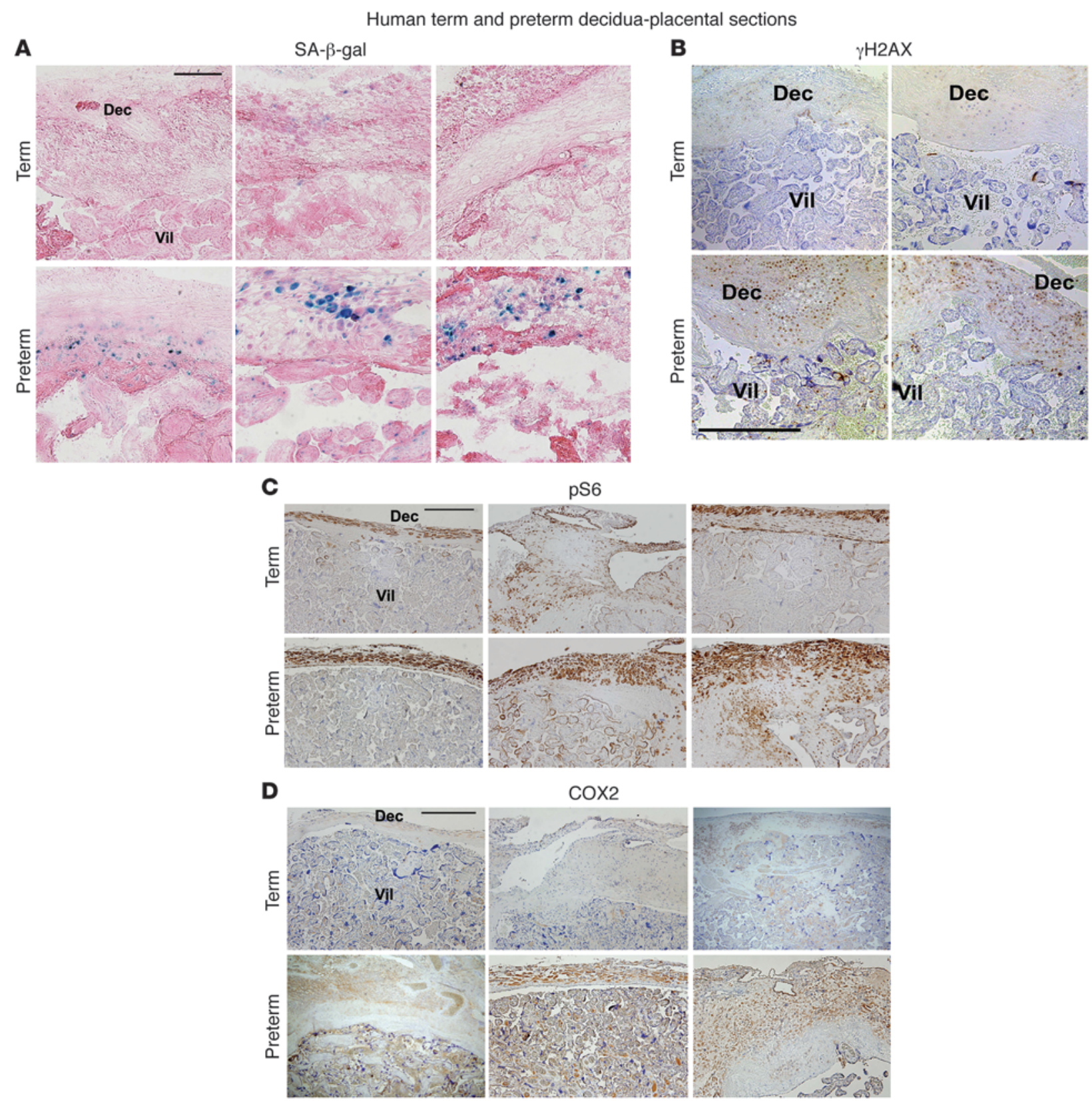

\section{Figure 4}

Heightened decidual senescence, mTORC1 signaling, and COX2 levels are evident in human preterm birth. (A) Three representative images of increased SA- $\beta$-gal staining (blue) in sections of preterm decidual-placental samples compared with those from term delivery. (B) Two representative images showing increased signals for $\gamma \mathrm{H} 2 \mathrm{AX}$, a senescence and DNA damage response marker, in preterm decidual-placental sections compared with those from term delivery. Immunostaining for pS6 (C) and COX2 (D) in sections of preterm decidual-placental samples compared with those from term delivery. The same 9 samples were processed as paraffin sections for COX2, pS6, and $\gamma \mathrm{H} 2 \mathrm{AX}$ immunostaining, while 9 additional samples were processed as frozen sections for SA- $\beta$-gal staining. Dec, decidua; Vil, villous trophoblast. Scale bars: $200 \mu \mathrm{m}$.

mental Figure 7B, Supplemental Figure 8, and ref. 31). Increased expression of these senescence markers correlated with increased immunostaining of COX2 and phosphorylated ribosomal protein $\mathrm{S} 6$ (pS6), a signature of heightened mTORC1 signaling (Figure 4, C and D, Supplemental Figure 7, C and D, and Supplemental Figure 8). To determine whether this decidual signature is specific to preterm delivery, we performed similar analyses in deciduaplacental sections from women undergoing non-laboring cesar- ean deliveries at 31-36 weeks gestation due to various pathologies, including preeclampsia, placenta previa, placental abruption, and fetal anomalies/distress. The signature was not observed in these deciduae (Supplemental Figure 9 and Supplemental Table 5). Collectively, the results provide evidence that decidual senescence is associated with higher mTORC1 and COX2 signaling in deciduae from preterm deliveries, corroborating the results in $\operatorname{Tr} p 53$ loxp $/$ loxP Pgr ${ }^{C r e /+}$ mice $(13,14)$. 
A

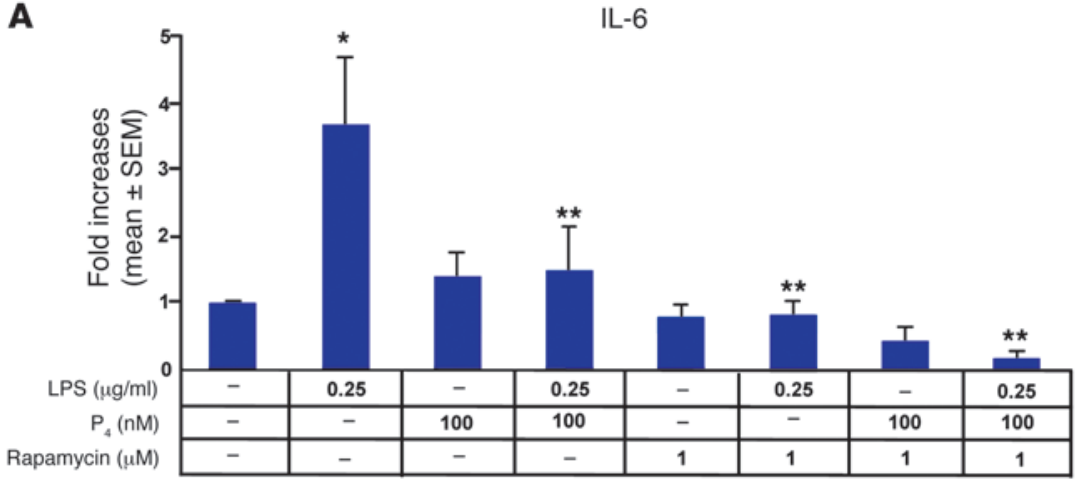

B

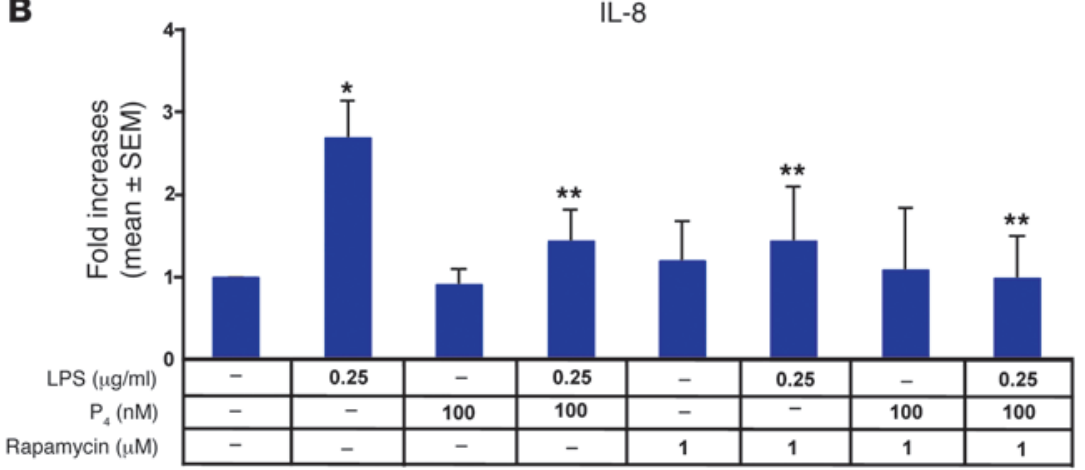

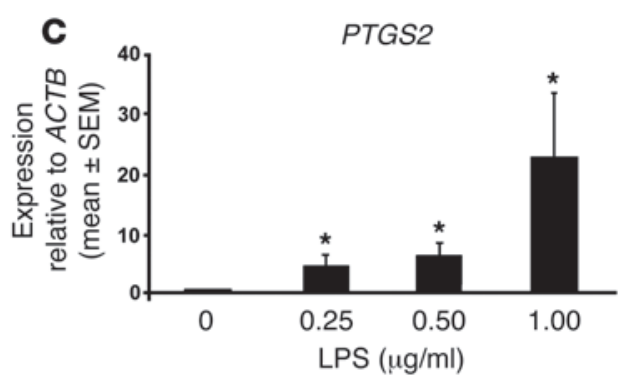

D
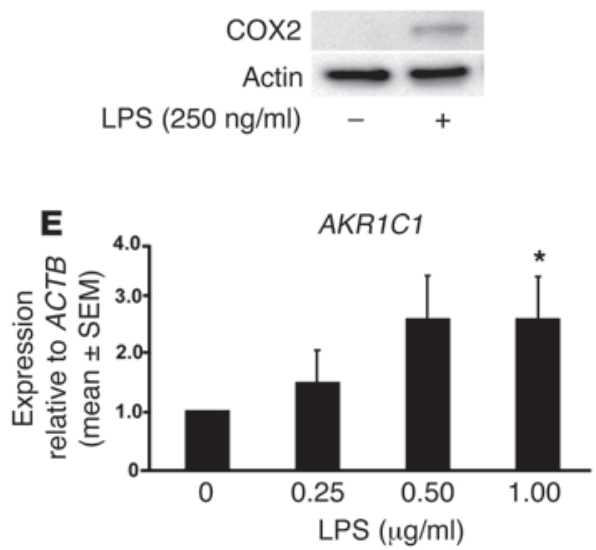

Figure 5

Levels of IL-6 and IL-8 and expression of PTGS2 and AKR1C1 in cultured human term decidual cells following exposure to LPS. (A and B) Decidual cells isolated from human term placentae showed increased secretion of IL-6 and IL-8 into culture media when exposed to LPS for 24 hours in culture; the levels were attenuated by treatment with rapamycin and/or $\mathrm{P}_{4}$ (mean $\pm \mathrm{SEM}$; ${ }^{*} P<0.05$ compared with vehicle-treated control; ${ }^{* *} P<0.05$ compared with LPS-treated cells). ELISA for IL-6 $(n=8)$ and IL-8 $(n=7)$ were repeated using independent samples. (C) qPCR results showed dose-dependent increases in decidual PTGS2 expression levels 6 hours after LPS exposure. Experiments were repeated in 3 independent samples (mean $\pm \mathrm{SEM} ;{ }^{*} P<0.05$ compared with control). (D) Western blotting showed increases in decidual COX2 levels. One representative blot from 3 independent experiments is shown. (E) qPCR showed dose-dependent increases in decidual $A K R 1 C 1$ expression levels 6 hours after LPS exposure. Experiments were repeated in 3 independent samples (mean $\pm \mathrm{SEM}$; ${ }^{*}<0.05$ compared with control).

$P_{4}$ and/or rapamycin attenuate LPS-induced IL-6 and IL-8 levels in cultured human decidual cells. With these results in hand, we questioned whether an inflammatory insult will provoke inflammatory cytokine production in decidual cells. Human decidual cells adherent to term placentae were isolated and cultured as previously described (32). Vimentin and cytokeratin immunostaining (markers of stroma-derived decidual cells and of ectoderm-derived trophoblast and amnion cells, respectively) confirmed that isolated decidual cells were approximately $99 \%$ pure and negative for CD45 (pan-immune cell marker) (Supplemental Figure 10A). Notably, TLR4 was expressed in decidual cells free of immune cells (Supplemental Figure 10B). Decidual cells were cultured in the presence or absence of TLR4-specific LPS. We found that decidual cells exposed to LPS secreted higher levels of IL-6 and IL-8 (Figure 5, A and B), with increased decidual COX2 at the protein and mRNA levels after LPS exposure (Figure 5, C and D). Intriguingly, higher expression levels of decidual $A K R 1 C 1$, encoding human $20 \alpha \mathrm{HSD}$, were also observed (Figure 5E), suggesting that the decidua can be a site for $\mathrm{P}_{4}$ metabolism.

Since $\mathrm{P}_{4}$ administration reduces the incidence of preterm birth in a specific population with higher risk of preterm birth and since $\mathrm{P}_{4}$ is considered immunosuppressive and antiinflammatory (33), LPStreated cells were cultured in the presence or absence of $\mathrm{P}_{4}(100 \mathrm{nM})$. We found that $\mathrm{P}_{4}$ reduced the levels of IL- 6 and IL- 8 in the spent media (Figure 5, A and B). We then asked whether mTORC1 inhibitor would also suppress the levels of these cytokines in the presence of LPS. Indeed, rapamycin $(1 \mu \mathrm{M})$ reduced the levels of IL-6 and IL-8 in the spent media (Figure 5, A and B), with further reduction by a combination of $\mathrm{P}_{4}$ and rapamycin (Figure 5, A and B). While higher levels of decidual PTGS2 after LPS exposure were suppressed by rapamycin, but not $\mathrm{P}_{4}$, higher levels of decidual AKR1C1 after LPS exposure were suppressed by rapamycin or $\mathrm{P}_{4}$ treatment (Supplemental Figure 11, A and B). Collectively, these results suggest that LPS can increase the release of inflammatory cytokines/mediators and the primary $\mathrm{P}_{4}$-metabolizing enzyme in decidual cells without the participation of immune cells, and that $\mathrm{P}_{4}$ and/or rapamycin can dampen these responses.

\section{Discussion}

The highlights of the present study are that: (a) genetically predisposed females with uterine deletion of Trp53 are more susceptible to preterm birth if exposed to a mild inflammatory stimulus; (b) under these conditions, preterm birth appears to involve both premature decidual senescence and ovarian luteolysis with a drop in $\mathrm{P}_{4}$ levels; (c) targeting premature decidual senescence by inhibiting mTORC1 signaling and compensating the drop in $\mathrm{P}_{4}$ levels by exogenous supplementation rescue preterm birth; (d) decidual senescence with increased mTORC1 and COX2 signaling is also 


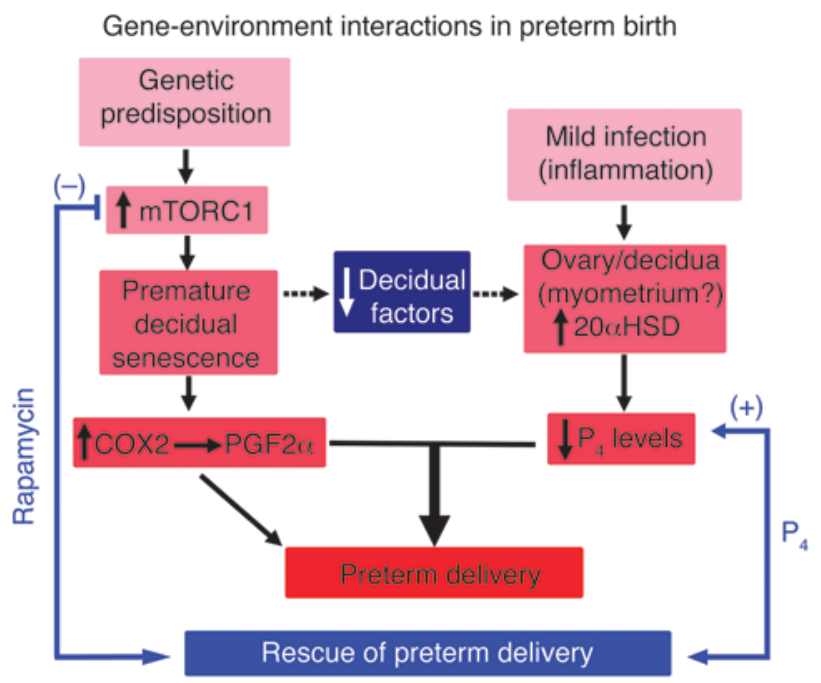

Figure 6

Proposed scheme of gene-environment interactions in preterm birth. In mice with uterine deletion of Trp53, premature decidual senescence arising from heightened decidual mTORC1 and COX2 signaling confers genetic predisposition to preterm birth. This genetic predisposition is remarkably aggravated by a mild inflammatory insult through a decrease in ovarian $\mathrm{P}_{4}$ levels due to increased expression of $20 \alpha \mathrm{HSD}$, a $\mathrm{P}_{4}$ metabolizing enzyme. Decidua-derived factors normally serve as luteotrophins to extend the CL lifespan; decidual health is presumably compromised in Trp53/oxPlloxP PgrCre/+ females due to premature senescence and reduced levels of decidual factors, conferring ovarian insufficiency and increased susceptibility to inflammation-mediated preterm birth.

evident in women undergoing preterm birth (Figure 6); and (e) cultured human term decidual cells respond to LPS, $\mathrm{P}_{4}$, and rapamycin, as predicted from mouse experiments.

Paradoxically, the role of p53 in aging is dependent upon its cellular and physiological context (34-37). It has been shown that inactivation of $\mathrm{p} 53$ in mouse embryonic fibroblasts results in heightened cellular senescence with increased mTORC1 signaling, which is attenuated by rapamycin (38). This is consistent with our present and previous in vivo findings (14). The finding that spontaneous preterm birth occurred in approximately $50 \%$ of $\operatorname{Trp} 53^{\text {loxP } / l o x P} \mathrm{Pgr}$ Cre/+ females with increased decidual senescence motivated us to ask whether another site of action could be targeted to reproducibly increase the incidence of preterm birth to $100 \%$ in $\operatorname{Trp} 53^{\operatorname{loxP} / \operatorname{lox} P} \mathrm{Pgr} \mathrm{Cre} /+$ females. Indeed, our present results showing preterm birth in all $\operatorname{Tr} p 53^{\operatorname{lox} P / \operatorname{lox} P} \mathrm{Pgr} \mathrm{Cre} /{ }^{+}$females treated with a low dose of LPS as opposed to none in floxed littermate females suggest that superimposition of even a mild inflammation on genetic predisposition can profoundly aggravate this phenotype. This raises the question as to the site of action of this second insult. While it is possible that $\operatorname{Tr} p 53^{\text {loxP/loxp }} \mathrm{Pgr}$ Cre/+ deciduae are more responsive to inflammation than floxed deciduae, our results showing signs of ovarian luteolysis with a drop in serum $\mathrm{P}_{4}$ levels after an exposure to $10 \mu \mathrm{g}$ LPS in $\operatorname{Tr} p 53^{\text {loxP/loxP } P g r C r e /+}$ females, but not in $\operatorname{Tr} p 53^{\text {loxP } / \text { loxP }} \mathrm{Pgr}^{+/+}$dams, suggest that the ovary is also a potential target of this inflammatory insult in $\operatorname{Trp} 53^{\operatorname{lox} P / \operatorname{lox} P} \mathrm{Pgr} \mathrm{Cre} /+$ females. Although other systemic effects of LPS cannot be ruled out, a previous study showed antigen-induced inflammation during early pregnancy induces luteolysis leading to pregnancy failure, which could be rescued by $\mathrm{P}_{4}$ supplementation (19); this is consistent with our present findings. There is evidence that higher doses of LPS (50-250 $\mu \mathrm{g})$ can trigger preterm birth in rodents with ovarian luteolysis and a decrease in $\mathrm{P}_{4}$ levels $(9,39)$.

Our results showing reduced expression of Prl3c1 and Prlr in deciduae of pregnant $\operatorname{Tr} p 53^{\operatorname{lox} P / \operatorname{lox} P} \mathrm{Pgr}$ Cre/+ mice suggest that increased sensitivity to ovarian luteolysis under mild inflammation could be due to decidual insufficiency. There is physiological and molecular evidence that decidual factors affect CL lifespan (20-23). Gibori's group has also shown that decidual "luteotrophins" regulate ovarian adenylyl cyclase activity, luteinizing hormone receptor, and steroidogenesis (40). In addition, we and others have previously shown that implantation failure in Prlr mutant females is rescued by $\mathrm{P}_{4}$ administration, suggesting its effect at the ovarian level $(29,30)$. However, Prlr is also expressed in the decidua, and $\mathrm{P}_{4}$-treated Prlr mutant mice fail to give a full complement of pups and show an increased number of resorptions even with continued $\mathrm{P}_{4}$ administration, suggesting the significance of decidual Prlr in supporting the later course of pregnancy. The importance of decidual health is also reflected in our present findings of rescue of preterm birth timing in LPS-treated $\operatorname{Trp} 53^{\text {loxP } / \text { loxP } P g r C r e /+}$ females with $\mathrm{P}_{4}$ alone, but with a large number of resorptions and fetal deaths ( 40\%) (Supplemental Table 1). In contrast, in LPS-treated $\operatorname{Trp} 53^{\text {loxP/loxP }} \mathrm{Pgr} \mathrm{Cre}^{++}$females, treatment with rapamycin and $\mathrm{P}_{4}$ not only rescued preterm birth but maintained fetal survival (91\% survival), which was comparable to that in floxed females under similar treatment conditions (Supplemental Table 2). It would be interesting to determine whether the decidua undergoing senescence influences CL function or whether both decidua and ovary are affected by inflammation in genetically predisposed females, such as $\operatorname{Tr} p 53^{\operatorname{lox} P / \operatorname{lox} P} \mathrm{Pgr} r^{\mathrm{Cr} /+}$ mice. Nonetheless, our results provide evidence that $\operatorname{Tr} p 53^{\text {loxP } / l o x P} P g r C r e /+$ deciduae and/or ovaries are more sensitive to exacerbation of preterm birth by inflammatory stimuli.

Our findings of decreased expression of $A K R 1 C 18$ by rapamycin and $\mathrm{P}_{4}$ are consistent with a previous observation of attenuation of AKR1C18 promoter activity in mouse luteal cells by rapamycin (21). We have previously shown that rapamycin inhibits decidual COX2 levels in $\operatorname{Trp} 53^{\text {loxP/loxP }} \mathrm{Pgr} \mathrm{Cre}^{\mathrm{Cr}+}$ females and in a cell line with increased mTORC1 activity (14). Moreover, our observations that attenuation of premature decidual senescence by rapamycin together with $\mathrm{P}_{4}$ supplementation prevents preterm birth in $\operatorname{Trp5} 3^{\text {loxP } / l o x P} \mathrm{Pgr}$ Cre/+ females exposed to a small dose of LPS - without any observable effects on fetal viability and growth - suggest that targeting decidual senescence and ovarian luteolysis is a potential therapy for preventing preterm birth in the context of genetic predisposition and infection/inflammation.

The therapeutic approach using rapamycin and $\mathrm{P}_{4}$ seems more desirable, since floxed mice given this therapy along with LPS did not appreciably show adverse effects on pregnancy outcome. A combinatory treatment with rapamycin and $\mathrm{P}_{4}$ with celecoxib also rescued preterm birth in $\operatorname{Tr} p 53^{\text {loxP/loxP } P g r C r e /+}$ females, but this regimen produced adverse effects on pregnancy outcome in floxed littermates. The reasons for the rescue of preterm birth with normal fetal viability and health in $\operatorname{Tr} p 53^{\text {loxP/loxP } P g r C r e /+}$ mice versus widespread fetal death and resorption in floxed mice is not clearly understood at this time, although it is possible that under normal pregnancy conditions, drug-drug interactions between celecoxib and rapamycin may adversely affect fetal survival. In fact, co-administration of rapamycin and NSAIDs is not clinically recommended (41). It is also possible that other PGs inhibited by this combination may be harm- 
ful to the overall health of normal pregnancy. Notably, celecoxib or rapamycin given alone in $\operatorname{Tr} p 53^{\text {loxP/loxP }} \mathrm{Pg} \mathrm{C}^{\mathrm{Cr} /+}$ females completely rescued spontaneous preterm birth and had no apparent effects on fetal viability or growth in deleted and floxed females $(13,14)$.

With regard to the doses and schedule of rapamycin and $\mathrm{P}_{4}$ treatments, rapamycin is normally given at a loading dose of $6 \mathrm{mg}$ followed by a daily oral maintenance dose of $2 \mathrm{mg}$ in transplant patients (42). However, the dosage depends on the response of the patient, and the daily maintenance dose can be up to the recommended limit of $40 \mathrm{mg}$ (43). In our mouse studies, we used only 3 intermittent doses of $0.25 \mathrm{mg} / \mathrm{kg} \mathrm{BW}$ rapamycin; however, it is difficult to directly compare the doses in mice and in humans due to differential metabolic and clearance rates of drugs.

Regarding the dose of $\mathrm{P}_{4}$, the use of $2 \mathrm{mg} \mathrm{P}_{4}$ in mouse studies is common and widespread in implantation and pregnancy maintenance $(12,44,45)$. Besides, we used only 2 doses of $\mathrm{P}_{4}$ on day 16 of pregnancy, which did not result in any adverse effects in floxed wild-type mice, delivering a full complement of healthy pups. In humans, there is a large range of $\mathrm{P}_{4}$ doses given via different routes and for variable lengths of treatment, and the American College of Obstetrics and Gynecology has not yet identified an appropriate dose, route, or formulation for $\mathrm{P}_{4}$ supplementation for the prevention of preterm birth (46). Two major clinical studies have shown that $\mathrm{P}_{4}$ supplementation can reduce the incidence of preterm delivery in select patient populations. One study used $250 \mathrm{mg}$ $17 \alpha$-hydroxyprogesterone caproate injections (i.m.) weekly from 16 to 20 weeks gestation until 37 weeks or delivery (47), while another study used $200 \mathrm{mg}$ vaginal $\mathrm{P}_{4}$ each night from 24 to 34 weeks gestation until 34 weeks (48). These long-term studies apparently did not show adverse effects on the mother and babies. Again, the doses used in these studies cannot directly be compared with mouse studies due to differential metabolic and clearance rates between the two species. Nonetheless, we believe that the dose of $\mathrm{P}_{4}$ we have used is an appropriate treatment for our present mouse studies.

In this mouse model, we address two known effectors of preterm birth and its rescue. However, the multifactorial aspects of human preterm delivery must be recognized and further studied. Extension of parturition timing but with poor neonatal outcome in LPS-treated Trp53 loxP/loxP $\mathrm{Pgr}$ Cre/+ females by $\mathrm{P}_{4}$ treatment alone suggests that it can address the ovarian insufficiency of $\mathrm{P}_{4}$ secretion but cannot overcome the adverse effects of premature decidual senescence. Indeed, there is evidence that $\mathrm{P}_{4}$ supplementation in humans can prevent preterm delivery only in certain patient populations with specific risk factors (47-51).

The role of p53 in pregnancy maintenance in relation to $\mathrm{P}_{4}$ levels and its responsiveness remain to be ascertained. There is evidence that certain TRP53 polymorphisms in women correlate with recurrent pregnancy failure (52); however, this issue remains unsettled (53). TRP53 polymorphisms have also been associated with aging and lifespan in humans $(36,54)$. Our recent proteomics study showed that deciduae in $\operatorname{Tr} p 53^{\text {loxP } / l o x P} \mathrm{Pgr} \mathrm{Cre} /++$ females manifest an increased signature for oxidative stress, with downregulation of many antioxidant enzymes, including PRDX6 (24). PRDX6 plays a role during pregnancy in mice with deletion of Fkbp52, an immunophilin co-chaperone for nuclear PR, which show reduced uterine $\mathrm{P}_{4}$ responsiveness (55-57). Therefore, it is possible that oxidative stress makes $\operatorname{Trp} 53^{\operatorname{loxP} / \operatorname{lox} P} \mathrm{Pgr} C \mathrm{Cr} /++$ females more sensitive to preterm birth, since it is considered a contributing factor $(1-3,8)$. In-depth studies will be required to assess the definitive role of p53 at various stages of pregnancy.
Our results are clinically relevant because some aspects of the molecular signature observed in mouse studies are consistent with those observed in deciduae of patients undergoing preterm birth. As presented here, it is remarkable that decidual senescence indicated by SA- $\beta$-gal and $\gamma \mathrm{H} 2 \mathrm{AX}$ staining $(58,59)$, along with higher mTORC1 and COX2 signaling, are also characteristics of human preterm deciduae. Interestingly, this signature was observed in deciduae irrespective of the etiology of preterm birth, ranging from unknown to diagnosed infection (e.g., chorioamnionitis). These results suggest that disparate signaling pathways converge toward mTORC1-induced decidual senescence and COX2 signaling. However, these studies must be repeated with a larger cohort of patients undergoing preterm birth. Nonetheless, the finding that $\mathrm{P}_{4}$ and/or rapamycin inhibited the inflammatory cytokine release from cultured human term decidual cells in response to LPS suggests that maintaining decidual health will help to prevent preterm birth. It is interesting that TLR4 is expressed in human decidual cells free of leukocytes, suggesting a direct effect of TLR4-mediated effects in the decidua in addition to the effects exerted by immune cells. Whether results from cultured decidual cells correctly reflect the effects of inflammation/ infection in vivo remains to be determined.

The placenta is a major source of $\mathrm{P}_{4}$ in human pregnancy after 10 weeks of gestation, as opposed to the situation in rodents, in which ovaries are the major source of $\mathrm{P}_{4}$ throughout the course of pregnancy (60). Although a decrease in $\mathrm{P}_{4}$ levels in rodent models of preterm birth is well established, peripheral $\mathrm{P}_{4}$ levels in women undergoing term and preterm delivery needs to be carefully assessed. A recent report from the United Kingdom shows decreases in salivary $\mathrm{P}_{4}$ levels in women undergoing preterm birth before 34 weeks of gestation; this study suggested that $\mathrm{P}_{4}$ levels are different in early preterm and late preterm birth (61). However, an earlier, U.S. study failed to observe such decline in salivary $\mathrm{P}_{4}$ levels (62). Therefore, $\mathrm{P}_{4}$ levels during human pregnancy in the context of the etiology of preterm birth and parturition timing remain unsettled. A recent report shows that microRNA-200a via STAT5b increases local metabolism of $\mathrm{P}_{4}$ by increasing the expression of AKR1C1 in immortalized human myometrial cells in culture (63). Another report shows $A K R 1 C 1$ expression in human deciduae (64). Our results showing increased $A K R 1 C 1$ expression levels in human term decidual cells in culture exposed to LPS, which could be attenuated by rapamycin or $\mathrm{P}_{4}$ treatment, suggest that decidua is also a site for $\mathrm{P}_{4}$ metabolism. It is interesting that the decidual PTGS2 levels are downregulated by rapamycin, which is consistent with our previous and present findings (14). Collectively, human studies showing different aspects of $\mathrm{P}_{4}$ signaling in parturition timing and multiple sites regulating $\mathrm{P}_{4}$ levels indicate that further investigation is warranted.

$\mathrm{P}_{4}$ executes its functions via two PR isoforms, PR-A and PR-B $(65,66)$. Analysis of promoter activity in cell culture systems suggests that while PR-A functions as a repressor, PR-B serves to increase $\mathrm{P}_{4}$ signaling (67). Notably, the placenta does not express $\mathrm{PR}$. Therefore, $\mathrm{P}_{4}$ should exert its effects via decidual or myometrial PR; which site of $\mathrm{P}_{4}$ signaling is more important in parturition remains to be ascertained. Functional withdrawal of $\mathrm{P}_{4}$ signaling in the myometrium has been proposed to trigger labor in humans (67). There could be several reasons for withdrawal: reduced $\mathrm{P}_{4}$ levels, local metabolism of $\mathrm{P}_{4}$ in the myometrium and/or decidua, an altered ratio of $\mathrm{PR}$ isoforms (PR-A/PR-B), or reduced transactivation or heightened transrepression due to recruitment of coactiva- 
tors or corepressors (68). There is also evidence that inflammation via NF- $\kappa \mathrm{B}$ can reduce $\mathrm{P}_{4}$ effectiveness and $\mathrm{PGF}_{2 \alpha}$ increases PR-A expression without affecting PR-B expression $(69,70)$. In addition, several studies reported that human labor is associated with reduced decidual expression of PR (71-73). Taken together, the evidence indicates that $\mathrm{P}_{4}$ signaling in the context of myometrial contractility in human parturition requires further investigation.

Chronological aging is a contributing factor to cellular senescence (74). Therefore, it is possible that uterine senescence due to maternal aging compounded by environmental stressors, such as infection/inflammation, can increase the risk of preterm birth. Epidemiologic evidence suggests that advanced maternal age is associated with human preterm birth (75-77). Furthermore, women of advanced maternal age undergoing ART procedures show higher incidence of preterm birth, even when receiving oocytes from young donors $(78,79)$, suggesting that uterine factors can contribute to this disorder.

Although gene-environment interactions are assumed to be major contributors to preterm birth, this concept has not been experimentally interrogated. Our studies in mice provide evidence that when a genetic predisposition is superimposed by mild inflammation, the rate of preterm birth is profoundly exaggerated. More importantly, success in reversing preterm birth in our mouse model by rapamycin and $\mathrm{P}_{4}$ provides clues to the cooperative contributions of at least two sites of action (decidua and ovary) toward preterm birth. Our present findings in mouse and human studies point toward decidual senescence as a contributor to preterm birth, a concept not previously entertained. These findings provide new insights and should encourage further investigation in the field. Future studies integrating findings from multiple models of preterm delivery will help to define the mechanism behind parturition timing and allow for the design of strategies to prevent preterm birth.

\section{Methods}

Mice. $\operatorname{Trp} 53^{\operatorname{loxP} / \operatorname{lox} P \mathrm{Pgr} \text { Cre/+ }}$ mice were generated as described previously (13). Briefly, $\operatorname{Trp} 53^{\operatorname{loxP} / \text { loxP }}$ mice (FVB/129) were crossed with $\mathrm{Pgr} \mathrm{Cre}^{\mathrm{C}+}$ mice (C57BL6/129) to generate mice with uterine deletion of $\operatorname{Tr} p 53$. Trp53 $53^{\operatorname{lox} P / l o x P}$ mice were obtained from the Mouse Models of Human Cancers Consortium, while $\mathrm{Pgr}_{\mathrm{C}} \mathrm{re} /+$ mice were initially provided by J.B. Lydon and F.J. DeMayo (Baylor College of Medicine, Houston, Texas, USA). For experiments, littermate $\operatorname{Tr} p 53^{\text {loxP/loxP }} \mathrm{Pgr}^{+/+}$and $\operatorname{Tr} p 53^{\operatorname{lox} P / \operatorname{lox} P} \mathrm{Pgr}$ Cre/+ mice were used. Mice were provided with autoclaved rodent LabDiet 5010 (Purina) and UV light-sterilized RO/DI constant circulation water ad libitum and were housed under a constant 12-hour light/12-hour dark cycle.

Analysis of parturition. Parturition events were monitored from day 16 through day 21 by observing mice daily, morning (0600h-0700h), noon (1200h), and evening (1800h-2000h). Birth timing was defined by the observation of the first born pup. Preterm birth was defined as birth occurring earlier than day 19 of pregnancy, with the day the vaginal plug was found designated day 1 of pregnancy. Dystocia was defined as difficult delivery lasting more than 12 hours. Resorption sites and placental scars were identified in dams showing preterm or difficult deliveries by examining the uterus after delivery. The number of pups/masses delivered were compared with the number resorption sites and placental scars identified.

Drug and LPS administration. Ultrapure TLR4-specific LPS (10, 37, 50, or $75 \mu \mathrm{g} /$ mouse, i.p.; Invivogen) was administered on day 16 of pregnancy at $1200 \mathrm{~h}$. The selective COX2 inhibitor celecoxib was suspended in 5\% PEG400 and 5\% Tween-80 dissolved in water by constant stirring and was given by oral gavage as indicated $(10 \mathrm{mg} / \mathrm{kg} \mathrm{BW} /$ dose $)$. The mTORC1 inhibitor rapamycin $(0.25 \mathrm{mg} / \mathrm{kg} \mathrm{BW} / \mathrm{d})$ was suspended in the same vehicle and given as a single oral gavage as indicated. The control group received vehicle alone. Progesterone was dissolved in sesame oil and administered subcutaneously ( $2 \mathrm{mg} / 0.1 \mathrm{ml} /$ dose $)$. Treatment schedules of various combinations of drugs are given in Supplemental Figure 4.

Measurement of $P G$ profiles. Implantation sites from which fetuses and placentae had been removed were collected on day 16 of pregnancy. These tissues were flash frozen and stored at $-80^{\circ} \mathrm{C}$ until used for extractions. Methanolic extracts of tissues were partially purified using $\mathrm{C} 18$ solid-phase extraction columns (Agilent), and PGs were quantified by HPLC-tandem mass spectrometry as previously described (13).

In situ bybridization. In situ hybridization was performed as described (13). Whole implantation sites were collected and flash frozen. Frozen tissue sections $(12 \mu \mathrm{m})$ were mounted onto baked poly-L-lysine-coated slides, fixed in cold $4 \%$ paraformaldehyde, acetylated, and hybridized at $45^{\circ} \mathrm{C}$ for 4 hours in formamide hybridization buffer containing ${ }^{35} \mathrm{~S}$-labeled $\mathrm{Plr} 3 c 1$ (a gift from Michael Soares, University of Kansas Medical Center, Kansas City, Kansas, USA) and Prlr (long isoform) cRNA probes. RNase A-resistant hybrids were detected by autoradiography after 3- to 10-day exposure by using Kodak NTB-2 liquid emulsion. To compare mRNA localization in $\operatorname{Tr} p 53^{\text {loxP/loxP }} \mathrm{Pgr}^{+/+}$and $\operatorname{Tr} p 53^{\text {loxP/loxP}} \mathrm{Pgr}{ }^{\mathrm{Cr} /+}+$ tissues, we placed sections of tissues of both genotypes under similar experimental conditions onto the same slide and processed them for hybridization.

Immunohistochemistry. Immunostaining was performed in formalin-fixed, paraffin-embedded sections using specific antibodies to 20 $\mathrm{\alpha HSD}$ (a gift from Geula Gibori, University of Illinois at Chicago, Chicago, Illinois, USA), COX2 (mouse, laboratory-generated; human, Santa Cruz Biotechnology Inc.), pS6 (Cell Signaling Technology), CDX2 (BioGenex), $\gamma \mathrm{H} 2 \mathrm{AX}$ (Millipore), vimentin (Dako), pan cytokeratin (Dako), and CD45 (Dako) as described previously $(13,14)$. Tissue sections from $\operatorname{Trp} 53^{\operatorname{lox} P / \operatorname{lox} P} \mathrm{Pgr}{ }^{+/+}$and $\operatorname{Trp} 53^{\text {loxP/loxP} P g r C r e /+}$ females on each day of pregnancy were processed onto the same slide.

$S A-\beta$-gal staining. Staining of SA- $\beta$-gal activity was performed as described previously $(13,14)$. In brief, frozen sections were fixed in $0.5 \%$ glutaraldehyde in PBS and stained for 6 hours in PBS (human tissues, $\mathrm{pH}$ 6.0; mouse tissues, pH 5.5) containing $1 \mathrm{mM} \mathrm{MgCl}, 1 \mathrm{mg} / \mathrm{ml} \mathrm{X-gal,} \mathrm{and} 5 \mathrm{mM}$ each of potassium ferricyanide and potassium ferrocyanide. Sections were counterstained with eosin.

Densitometry ofstaining. The images of SA- $\beta$-gal staining and immunostaining were analyzed using inForm Image analysis software (PerkinElmer), which can detect the average signal intensity in the scanned area.

RNA isolation and quantitative PCR. RNA was prepared from homogenized tissues using TRIzol reagent (Invitrogen). RNA extraction was performed as described previously $(13,14)$. Quantitative PCR (qPCR) was performed using StepOnePlus Real-Time PCR System (Applied Biosciences). PCR was performed using the following primers: $5^{\prime}$-CTCTGAAGCCAGGGAATGAG-3' and 5'-ATGGCATTCTACCTGGTTGC-3' for mouse Akr1c18 (encoding 20 $\alpha \mathrm{HSD}$ ) (product size, $221 \mathrm{bp}$ ); 5'-TGTGCCGCAGCATTAAGTG-3' and $5^{\prime}$-GGCATCTCACCCTCCACAAC- $3^{\prime}$ for mouse Socs 1 (product size, $125 \mathrm{bp}$ ); 5'-TGCTGGCCAAAGAAATAACCA-3' and 5'-GGTCACCCCTTGCCACTCT-3' for mouse Socs3 (product size, 88 bp); 5'-TCCATGACAACTTTGGCATTG- ${ }^{\prime}$ and 5'-CAGTCTTCTGGGTGGCAGTGA-3' for mouse Gapdh (product size, 72 bp); 5'-GATTGCCCGACTCCCTTGG-3' and 5'-GTCTAGCCAGAGTTTCACCGT- $3^{\prime}$ for human PTGS2 (encoding COX2) (product size, $250 \mathrm{bp}$ ); 5'-TGTGCGATATTTGACCCTTGA-3' and 5'-TGCTGTAGCTTGCTGAAATCAC-3' for human AKR1C1 (product size, 204 bp); 5'-CAACAAAGGTGGGAATGCTT-3' and 5'-TGCCATTGAAAGCAACTCTG-3' for human TLR4 (product size, $317 \mathrm{bp}$ ); and $5^{\prime}$-CACACTGTGCCCATCTACGA-3' and 5'-CTCCTTAATGTCACGCACGA-3' for human ACTB (product size, $162 \mathrm{bp}$ ). Gapdh and $A C T B$ served as housekeeping genes for mouse tissues and human cells, respectively. 
Measurement of $\mathrm{P}_{4}$ levels. Mouse blood samples were collected on day 16 of pregnancy at the prescribed time after treatments. Serum levels of $\mathrm{P}_{4}$ were measured by EIA kits (Cayman Chemical).

Human samples. Term and preterm placentae were obtained from women with singleton vaginal term or preterm delivery. Placental samples from patients with hydramnios or newborns with any birth or chromosomal abnormalities were not included in the preterm study, although placental samples from patients with chorioamnionitis or preterm premature rupture of the membranes (PPROM) were included in the study. Detailed patient information for immunohistochemistry and SA- $\beta$-gal staining is shown in Supplemental Table 4. Placental samples from non-laboring patients undergoing cesarean section for preeclampsia, fetal distress/ anomaly, placenta abruption, or previa were included as controls for the study (Supplemental Table 5). For decidual cell culture, term placentae were obtained from women undergoing elective cesarean section. Endometria for endometrial stromal cell culture were obtained from women undergoing hysterectomy due to benign gynecological diseases; none had hormone treatment 3 months prior to surgery. None of the women undergoing term vaginal delivery or term cesarean section showed any clinical or pathological signs of preterm delivery, infection, or other maternal or placental diseases. All women with singleton preterm vaginal delivery did not show clinical or pathological signs of other maternal or placental diseases apart from preterm delivery. Newborns did not have any apparent birth or chromosomal abnormalities.

Isolation and culture of human decidual cells. Human term decidual cells were isolated and cultured according to previously described protocols with minor modifications $(32,80)$. Briefly, term deciduae from women with cesarean section were scraped from the maternal surface of the chorion, minced, and digested in Ham's F-10 media containing $25 \mathrm{mg} / \mathrm{ml}$ collagenase and $6.25 \mathrm{U} / \mathrm{ml}$ DNase in a shaking water bath at $37^{\circ} \mathrm{C}$ for 30 minutes. Digested samples were passed through a 23 -gauge needle to dissociate remaining cell clusters, centrifuged at $250 \mathrm{~g}$ for 5 minutes, and washed in the culture media. The cell pellet was resuspended in 20\% Percoll, layered on a discontinuous (60\%:50\%:40\%) Percoll gradient, and centrifuged at $540 \mathrm{~g}$ for 20 minutes. The upper cell layer was collected, washed, centrifuged, resuspended in $40 \%$ Percoll, layered on a discontinuous (55\%:50\%:45\%) Percoll gradient, and centrifuged at $540 \mathrm{rpm}$ for $20 \mathrm{~min}$. The upper cell layer was washed and resuspended in DMEM/F-12 media containing $5 \%$ fetal bovine serum, $100 \mathrm{IU} / \mathrm{ml}$ penicillin, $0.1 \mathrm{mg} / \mathrm{ml}$ streptomycin, and $0.25 \mu \mathrm{g} / \mathrm{ml}$ amphotericin $\mathrm{B}$ and plated onto $100-\mathrm{mm}$ dishes. Cells were cultured at $37^{\circ} \mathrm{C}$ in a humidified $5 \% \mathrm{CO}_{2}$ chamber. When the cells attained confluence, they were dissociated with $0.25 \%$ trypsinEDTA, harvested by centrifugation at $250 \mathrm{~g}$ for 5 minutes, and replated onto $100-\mathrm{mm}$ dishes. Cells were passaged at least 3 times and plated in 12 -well plates at $2 \times 10^{5}$ cells/well for experiments. The complete media were then removed and replaced with serum-free media containing antibiotics, and cells were cultured for an additional 12-24 hours before stimulation. Purity of the decidual cell population was determined by immunocytochemical staining of vimentin, pan-cytokeratin, and CD45, which served as markers for stromal cells, epithelial cells, and leukocytes, respectively. The purity of the passaged decidual cells was greater than $99 \%$, as judged by positive staining for vimentin and negative staining for cytokeratin and CD45 (Supplemental Figure 10A).

Treatment of buman term decidual cells. To evaluate the effects of LPS on expression of PTGS2 and AKR1C1 in term decidual cells, wells were replenished with serum-free media with or without TLR4-specific LPS and cells were incubated for 6 hours (qPCR) or 24 hours (Western blotting). After termination of cultures, total RNA or protein was isolated and used for qPCR or Western blotting, respectively. To evaluate the effects of $\mathrm{P}_{4}$ and rapamycin on LPS-induced levels of PTGS2 and AKR1C1, cells were preincubated with $\mathrm{P}_{4}$ or rapamycin for 24 hours before addition of LPS and cultured for an additional 24 hours. To evaluate the effects of $\mathrm{P}_{4}$ and rapamycin on LPS-induced levels of IL- 6 and IL-8, conditioned media were collected after termination of cultures, centrifuged, and stored at $-80^{\circ} \mathrm{C}$ until assay. Concentrations of IL- 6 and IL- 8 were measured using specific ELISA kits according to the manufacturer's protocol (R\&D Systems). Absorbance was read at $450 \mathrm{~nm}$ with a DigiScan Microplate Reader.

Western blotting. Protein extraction and Western blotting were performed as previously described $(13,14)$. Antibodies to COX2 and actin (Santa Cruz Biotechnology Inc.) were used. Bands were visualized by using an ECL Prime Western blotting detection system (GE Healthcare). Actin served as a loading control.

Statistics. Statistical analyses were performed using 2-tailed Student's $t$ test. $P$ values less than 0.05 were considered statistically significant.

Study approval. All mice used in this investigation were housed in the Cincinnati Children's Hospital Medical Center Animal Care Facility according to NIH and institutional guidelines for the use of laboratory animals. All protocols of the present study were reviewed and approved by the Cincinnati Children's Hospital Research Foundation Institutional Animal Care and Use Committee. Collection and processing of human samples were approved by the respective ethics committees at University of Tokyo and Yaizu City Hospital in Tokyo under the approved IRB protocol no. 3456, and all patients provided written informed consent. Tissue sample collections were based on the operating procedures of the University of Tokyo Tissue Procurement Resource, which strips samples of all patient identifiers before procurement (de-identified) and replaces these with new sample identifiers. This study was limited to female subjects because of the nature of the disease studied. Children were not included due to the rarity of preterm birth in the pediatric population.

\section{Acknowledgments}

We thank Tomoyuki Fujii, Yutaka Osuga, Kaori Koga (University of Tokyo, Tokyo, Japan), and Kazutoshi Naritaka (Yaizu City Hospital, Japan) for human sample collections and helpful discussions and Michael J. Soares (Kansas University Medical Center) for providing the Prl3c1 cDNA. This work was supported in part by grants from the NIH (HD12304 and DA06668), the March of Dimes (\#21-FY12-127 and \#22-FY13-543), and the Bill and Melinda Gates Foundation through the Grand Challenges Explorations Initiative (to S.K. Dey); by PRESTO, a Grant-in-Aid for Scientific Research from the Japan Society for the Promotion of Science, the Takeda Science Foundation, the Kowa Life Science Foundation, and the Yamaguchi Endocrine Research Foundation (to Y. Hirota); and by NIH/National Institute on Drug Abuse grant DA032150 (to H. Bradshaw). J. Cha is a predoctoral National Research Service Award fellow (NIA/NIH F30AG040858) of the University of Cincinnati Medical Scientist Training Program (T32GM063483).

Received for publication March 25, 2013, and accepted in revised form May 23, 2013.

Address correspondence to: Sudhansu K. Dey, Cincinnati Children's Research Foundation, Division of Reproductive Sciences, MLC 7045, 3333 Burnet Avenue, Cincinnati, Ohio 45229-3039, USA. Phone: 513.803.1158; Fax: 513.803.1160; E-mail: sk.dey@cchmc.org. Or to: Yasushi Hirota, Department of Obstetrics and Gynecology, Graduate School of Medicine, University of Tokyo, 7-3-1 Hongo, Bunkyo-ku, Tokyo 113-8655, Japan. Phone: 81.3.5800.9044; Fax: 81.3.5800.9799; E-mail: yhirota-tky@umin.ac.jp. 
1. WHO. Born Too Soon: The Global Action Report on Preterm Birth. Geneva, Switzerland: World Health Organization; 2012.

2. Behrman R, Butler AS, eds. Preterm Birth: Causes, Consequences, and Prevention. Washington DC, USA: The National Academies Press; 2007.

3. Goldenberg RL, Culhane JF, Iams JD, Romero R. Epidemiology and causes of preterm birth. Lancet. 2008;371(9606):75-84.

4. Blencowe $\mathrm{H}$, et al. National, regional, and worldwide estimates of preterm birth rates in the year 2010 with time trends since 1990 for selected countries: a systematic analysis and implications. Lancet. 2012;379(9832):2162-2172

5. Saigal S, Doyle LW. An overview of mortality and sequelae of preterm birth from infancy to adulthood. Lancet. 2008;371(9608):261-269.

6. Liu L, et al. Global, regional, and national causes of child mortality: an updated systematic analysis for 2010 with time trends since 2000. Lancet. 2012;379(9832):2151-2161

7. Moster D, Lie RT, Markestad T. Long-term medical and social consequences of preterm birth. $N$ Engl J Med. 2008;359(3):262-273.

8. Muglia LJ, Katz M. The enigma of spontaneous preterm birth. NEngl J Med. 2010;362(6):529-535.

9. Elovitz MA, Mrinalini C. Animal models of preterm birth. Trends Endocrinol Metab. 2004;15(10):479-487.

10. Dudley DJ, Branch DW, Edwin SS, Mitchell MD. Induction of preterm birth in mice by RU486. Biol Reprod. 1996;55(5):992-995

11. Challis JRG, Matthews SG, Gibb W, Lye SJ. Endocrine and paracrine regulation of birth at term and preterm. Endocr Rev. 2000;21(5):514-550.

12. Cha J, Sun X, Dey SK. Mechanisms of implantation: strategies for successful pregnancy. Nat Med. 2012;18(12):1754-1767.

13. Hirota Y, Daikoku T, Tranguch S, Xie H, Bradshaw HB, Dey SK. Uterine-specific p53 deficiency confers premature uterine senescence and promotes preterm birth in mice. J Clin Invest. 2010;120(3):803-815.

14. Hirota Y, Cha J, Yoshie M, Daikoku T, Dey SK. Heightened uterine mammalian target of rapamycin complex 1 (mTORC1) signaling provokes preterm birth in mice. Proc Natl Acad Sci U S A. 2011; 108(44):18073-18078.

15. Renthal NE, Chen CC, Williams KC, Gerard RD, Prange-Kiel J, Mendelson CR. miR-200 family and targets, ZEB1 and ZEB2, modulate uterine quiescence and contractility during pregnancy and labor. Proc Natl Acad Sci U S A. 2010;107(48):20828-20833.

16. Simhan HN, Caritis SN. Prevention of preterm delivery. N Engl J Med. 2007;357(5):477-487.

17. Ratajczak CK, Muglia LJ. Insights into parturition biology from genetically altered mice. Pediatr Res. 2008;64(6):581-589.

18. Barkai U, Prigent-Tessier A, Tessier C, Gibori GB, Gibori G. Involvement of SOCS-1, the suppressor of cytokine signaling, in the prevention of prolactin-responsive gene expression in decidual cells. Mol Endocrinol. 2000;14(4):554-563.

19. Erlebacher A, Zhang D, Parlow AF, Glimcher LH Ovarian insufficiency and early pregnancy loss induced by activation of the innate immune system. J Clin Invest. 2004;114(1):39-48.

20. Herz Z, Khan I, Jayatilak PG, Gibori G. Evidence for the secretion of decidual luteotropin: a prolactinlike hormone produced by rat decidual cells. Endocrinology. 1986;118(6):2203-2209.

21. Bao L, et al. Decidual prolactin silences the expression of genes detrimental to pregnancy. Endocrinology. 2007;148(5):2326-2334.

22. Jayatilak PG, Glaser LA, Basuray R, Kelly PA, Gibori G. Identification and partial characterization of a prolactin-like hormone produced by rat decidual tissue. Proc Natl Acad Sci US A. 1985;82(1):217-221.

23. Gibori G, Rothchild I, Pepe GJ, Morishige WK, Lam $P$. Luteotrophic action of decidual tissue in the rat.
Endocrinology. 1974;95(4):1113-1118.

24. Burnum KE, et al. Uterine deletion of Trp53 compromises antioxidant responses in the mouse decidua. Endocrinology. 2012;153(9):4568-4579.

25. Alam SM, Konno T, Sahgal N, Lu L, Soares MJ. Decidual cells produce a heparin-binding prolactin family cytokine with putative intrauterine regulatory actions. J Biol Chem. 2008;283(27):18957-18968.

26. Hiraoka Y, et al. PLP-I: a novel prolactin-like gene in rodents. Biochim Biophys Acta. 1999;1447(2-3):291-297.

27. Toft DJ, Linzer DI. Prolactin (PRL)-like protein J, a novel member of the PRL/growth hormone family, is exclusively expressed in maternal decidua. Endocrinology. 1999;140(11):5095-5101.

28. Ishibashi $\mathrm{K}$, Imai M. Identification of four new members of the rat prolactin/growth hormone gene family. Biochem Biophys Res Commun. 1999; 262(3):575-578.

29 . Binart N, et al. Rescue of preimplantatory egg development and embryo implantation in prolactin receptor-deficient mice after progesterone administration. Endocrinology. 2000;141(7):2691-2697.

30. Reese J, et al. Implantation and decidualization defects in prolactin receptor (PRLR)-deficient mice are mediated by ovarian but not uterine PRLR. Endocrinology. 2000;141(5):1872-1881.

31. Mah LJ, El-Osta A, Karagiannis TC. GammaH2AX as a molecular marker of aging and disease. Epigenetics. 2010;5(2):129-136.

32. Mackenzie AP, Schatz F, Krikun G, Funai EF, Kadner S, Lockwood CJ. Mechanisms of abruption-induced premature rupture of the fetal membranes: thrombin enhanced decidual matrix metalloproteinase-3 (stromelysin-1) expression. Am J Obstet Gynecol. 2004;191(6):1996-2001.

33. Siiteri PK, Febres F, Clemens LE, Chang RJ, Gondos B, Stites D. Progesterone and maintenance of pregnancy: is progesterone nature's immunosuppressant? Ann N Y Acad Sci. 1977;286:384-397.

34. Matheu A, et al. Delayed ageing through damage protection by the Arf/p53 pathway. Nature. 2007;448(7151):375-379.

35. Feng Z, Hu W, Teresky AK, Hernando E, CordonCardo C, Levine AJ. Declining p53 function in the aging process: a possible mechanism for the increased tumor incidence in older populations. Proc Natl Acad Sci US A. 2007;104(42):16633-16638.

36. Rodier F, Campisi J, Bhaumik D. Two faces of p53: aging and tumor suppression. Nucleic Acids Res. 2007; 35(22):7475-7484

37. Donehower LA. Using mice to examine p53 functions in cancer, aging, and longevity. Cold Spring Harb Perspect Biol. 2009;1(6):a001081.

38. Demidenko ZN, Korotchkina LG, Gudkov AV, Blagosklonny MV. Paradoxical suppression of cellular senescence by p53. Proc Natl Acad Sci U S A. 2010; 107(21):9660-9664

39. Telleria CM, Ou J, Sugino N, Ferguson S, Gibori G. The expression of interleukin- 6 in the pregnant rat corpus luteum and its regulation by progesterone and glucocorticoid. Endocrinology. 1998; 139(8):3597-3605.

40. Gibori G, Kalison B, Basuray R, Rao MC, HunzickerDunn M. Endocrine role of the decidual tissue: decidual luteotropin regulation of luteal adenylyl cyclase activity, luteinizing hormone receptors, and steroidogenesis. Endocrinology. 1984;115(3):1157-1163.

41. Mignat C. Clinically significant drug interactions with new immunosuppressive agents. Drug Saf. 1997;16(4):267-278.

42. Kahan BD. Efficacy of sirolimus compared with azathioprine for reduction of acute renal allograft rejection: a randomised multicentre study. The Rapamune US Study Group. Lancet. 2000; 356(9225):194-202

43. Rapamune (sirolimus) maintenance regimen. Summary for presentation to the Subcomittee of the Antiviral Drugs Advisory Commit- tee on Immunosuppressive Drugs. 24 January 2002. http:/www.fda.gov/ohrms/dockets/ac/02/ briefing/3832b1_01_Wyreth-Ayerst.pdf. Accessed August 12, 2013.

44. Dey SK, et al. Molecular cues to implantation. Endocr Rev. 2004;25(3):341-373.

45. Wang H, Dey SK. Roadmap to embryo implantation: clues from mouse models. Nat Rev Genet. 2006; 7(3):185-199.

46. American College of Obstetrics and Gynecologist Committee Opinion. Use of progesterone to reduce preterm birth. Int J Gynaecol Obstet. 2004;84(1):93-94.

47. Meis PJ, et al. Prevention of recurrent preterm delivery by 17 alpha-hydroxyprogesterone caproate. NEngl J Med. 2003;348(24):2379-2385.

48. Fonseca EB, Celik E, Parra M, Singh M, Nicolaides $\mathrm{KH}$, Fetal Medicine Foundation Second Trimester Screening G. Progesterone and the risk of preterm birth among women with a short cervix. $N$ Engl J Med. 2007;357(5):462-469.

49. Johnson JW, Austin KL, Jones GS, Davis GH, King TM. Efficacy of 17alpha-hydroxyprogesterone caproate in the prevention of premature labor. $N \mathrm{EnglJ}$ Med. 1975;293(14):675-680.

50. Romero R. Prevention of spontaneous preterm birth: the role of sonographic cervical length in identifying patients who may benefit from progesterone treatment. Ultrasound Obstet Gynecol. 2007; 30(5):675-686

51. Romero R, Yeo L, Miranda J, Hassan SS, CondeAgudelo A, Chaiworapongsa T. A blueprint for the prevention of preterm birth: vaginal progesterone in women with a short cervix. J Perinat Med. 2013;41(1):27-44.

52. Kang HJ, et al. Single-nucleotide polymorphisms in the 553 pathway regulate fertility in humans. Proc Natl Acad Sci U S A. 2009;106(24):9761-9766.

53. Patounakis G, Treff N, Tao X, Lonczak A, Scott RT, Frattarelli JL. The p53 codon 72 single nucleotide polymorphism lacks a significant effect on implantation rate in fresh in vitro fertilization cycles: an analysis of 1,056 patients. Fertil Steril. 2009; 92(4):1290-1296

54. de Keizer PL, Laberge RM, Campisi J. p53: proaging or pro-longevity? Aging (Albany NY). 2010; 2(7):377-379

55. Tranguch $\mathrm{S}$, et al. Cochaperone immunophilin FKBP52 is critical to uterine receptivity for embryo implantation. Proc Natl Acad Sci U S A. 2005; 102(40):14326-14331.

56. Tranguch S, Wang H, Daikoku T, Xie H, Smith DF, Dey SK. FKBP52 deficiency-conferred uterine progesterone resistance is genetic background and pregnancy stage specific. J Clin Invest. 2007; 117(7):1824-1834.

57. Hirota Y, et al. Uterine FK506-binding protein 52 (FKBP52)-peroxiredoxin-6 (PRDX6) signaling protects pregnancy from overt oxidative stress. Proc Natl Acad Sci U S A. 2010;107(35):15577-15582.

58. Krizhanovsky V, et al. Senescence of activated stellate cells limits liver fibrosis. Cell. 2008;134(4):657-667.

59. Sedelnikova OA, Horikawa I, Zimonjic DB, Popescu NC, Bonner WM, Barrett JC. Senescing human cells and ageing mice accumulate DNA lesions with unrepairable double-strand breaks. Nat Cell Biol. 2004;6(2):168-170.

60. Villee DB. Development of endocrine function in the human placenta and fetus (second of two parts). N Engl J Med. 1969;281(10):533-541.

61. Lachelin GC, McGarrigle HH, Seed PT, Briley A, Shennan AH, Poston L. Low saliva progesterone concentrations are associated with spontaneous early preterm labour (before 34 weeks of gestation) in women at increased risk of preterm delivery. BJOG. 2009;116(11):1515-1519.

62. Klebanoff MA, et al. Salivary progesterone and estriol among pregnant women treated with 17-alpha-hydroxyprogesterone caproate or placebo. 
Am J Obstet Gynecol. 2008;199(5):506.e1-506.e7.

63. Williams KC, Renthal NE, Condon JC, Gerard RD, Mendelson CR. MicroRNA-200a serves a key role in the decline of progesterone receptor function leading to term and preterm labor. Proc Natl Acad SciUS A. 2012;109(19):7529-7534.

64. Nakajima T, et al. Expression of 20alpha-hydroxysteroid dehydrogenase mRNA in human endometrium and decidua. Endocr J. 2003;50(1):105-111.

65. Pieber D, Allport VC, Hills F, Johnson M, Bennett $\mathrm{PR}$. Interactions between progesterone receptor isoforms in myometrial cells in human labour. Mol Hum Reprod. 2001;7(9):875-879.

66. Pieber D, Allport VC, Bennett PR. Progesterone receptor isoform $\mathrm{A}$ inhibits isoform B-mediated transactivation in human amnion. Eur J Pharmacol. 2001;427(1):7-11.

67. Mesiano S, Wang Y, Norwitz ER. Progesterone receptors in the human pregnancy uterus: do they hold the key to birth timing? Reprod Sci. 2011; 18(1):6-19

68. Brown AG, Leite RS, Strauss JF. Mechanisms underlying "functional" progesterone withdrawal at parturition. Ann N Y Acad Sci. 2004;1034:36-49.
69. van der Burg B, van der Saag PT. Nuclear factorkappa-B/steroid hormone receptor interactions as a functional basis of anti-inflammatory action of steroids in reproductive organs. Mol Hum Reprod. 1996;2(6):433-438.

70. Madsen G, Zakar T, Ku CY, Sanborn BM, Smith R, Mesiano S. Prostaglandins differentially modulate progesterone receptor- $\mathrm{A}$ and - $\mathrm{B}$ expression in human myometrial cells: evidence for prostaglandin-induced functional progesterone withdrawal. J Clin Endocrinol Metab. 2004;89(2):1010-1013.

71. Goldman S, Weiss A, Almalah I, Shalev E. Progesterone receptor expression in human decidua and fetal membranes before and after contractions: possible mechanism for functional progesterone withdrawal. Mol Hum Reprod. 2005;11(4):269-277.

72. Merlino A, et al. Nuclear progesterone receptor expression in the human fetal membranes and decidua at term before and after labor. Reprod Sci. 2009;16(4):357-363.

73. Lockwood CJ, Stocco C, Murk W, Kayisli UA, Funai EF, Schatz F. Human labor is associated with reduced decidual cell expression of progesterone, but not glucocorticoid, receptors. J Clin Endocrinol
Metab. 2010;95(5):2271-2275.

74. Collado M, Blasco MA, Serrano M. Cellular senescence in cancer and aging. Cell. 2007;130(2):223-233.

75. Cnattingius S, Forman MR, Berendes HW, Isotalo L. Delayed childbearing and risk of adverse perinatal outcome. A population-based study. JAMA. 1992;268(7):886-890.

76. Roberts CL, Algert CS, March LM. Delayed childbearing--are there any risks? Med J Aust. 1994; 160(9):539-544.

77. Carolan M. The graying of the obstetric population: implications for the older mother. $J$ Obstet Gynecol Neonatal Nurs. 2003;32(1):19-27.

78. Nelson SM, Lawlor DA. Predicting live birth, preterm delivery, and low birth weight in infants born from in vitro fertilisation: a prospective study of 144,018 treatment cycles. PLoS Med. 2011;8(1):e1000386.

79. Krieg SA, Henne MB, Westphal LM. Obstetric outcomes in donor oocyte pregnancies compared with advanced maternal age in in vitro fertilization pregnancies. Fertil Steril. 2008;90(1):65-70.

80. Hirata T, et al. Evidence for the presence of tolllike receptor 4 system in the human endometrium. JClin Endocrinol Metab. 2005;90(1):548-556. 